

\section{DISCLAIMER}

Portions of this document may be illegible in electronic image products. Images are produced from the best available original document. 


\section{NOTICE}

This report was prepared as an account of work sponsored by the United States Government. Neither the United States nor the U.S. Department of Energy (DOE), nor any of its employes, nor any of its contractors, subcontractors or their employes, makes any warranty, expressed or implied, or assumes any legal liability or responsibility for any third party's use or the results of such use of any information, apparatus, product or process disclosed in this report, or represents that its use by such third party would not infringe privately owned rights.

Printed in the United States of America

Available from

National Technical Information Service

U.S. Department of Commerce

5285 Port Royal Road

Springfield, VA 22161

NTIS price codes

Printed copy: A 04

Microfiche copy: A01 


\title{
AN ASSESSMENT OF THE NEED FOR DRY COOLING 1981 UPDATE
}

\author{
HEDL-THE- $-81-47$
}

DE82 009395

\section{Hanford Engineering Development Laboratory \\ J.C. Sonnichsen January 1982}

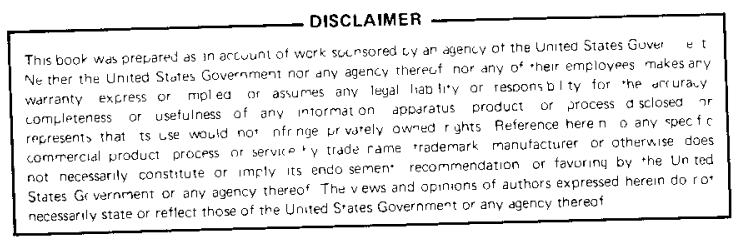


- 


\title{
AN ASSESSMENT OF THE NEED FOR DRY COOLING
}

1981 UPDATE

\author{
J. C. Sonnichsen
}

\begin{abstract}
This report documents an assessment of the need for dry cooling of steam-electric power plants over the time period 2000-2020, which was performed by the Hanford Engineering Development Laboratory (HEDL). In the assessment three scenarios for future growth in electrical energy were examined. Characteristics of fresh water supply and consumptive use of water in each of the 99 aggregated subareas within the contiguous United States were reviewed; based on this review the need for dry cooling in each pertinent subarea was delineated.
\end{abstract}


- 
Abstract

Figures

Tables

viji

1.0

INTRODUCTION

1.1 PURPOSE \& SCOPE

$1-4$

1.2 SUMMARY AND CONCLUSIONS $1-6$

2.0 ENERGY DEMAND $2-1$

2.1 ENERGY USE BY ECONOMIC SECTORS 2-1

2.2 ELECTRICAL ENERGY DEMAND FORECAST 2-3

2.2.1 Electrical Energy Growth Forecasts

2.2.2 Electrical Energy Growth Forecasts (2000-2020)

2.3 ENERGY FROM SYNTHETIC FUELS 2-6

2.3.1 Synthetic Fuel From Coal 2-6

2.3.2 Synthetic Fuel From 0il Shale 2-9

3.0 ENERGY SUPPLY 3-1

3.1 FORECASTS OF INSTALLED ELECTRICAL GENERATION CAPACITY

3.1.1 Electrical Energy Capacity Scenarios

3.1.2 Electrical Energy Capacity Scenarios (2000-2020)

3.2 FORECAST OF SYNFUEL PLANTS 3-4

4.0 WATER RESOURCES 4-1

4.1 COMPETING DEMANDS FOR WATER 4-2

\subsection{IDENTIFICATION AND DISCUSSION OF WATER} RESOURCE CONDITIONS IN POTENTIALLY WATERSHORT ASAS 


\section{CONTENTS (Cont'd)}

Page

4.3 WATER REQUIRED BY ENERGY

4.3.1 Water Requirements for Cooling Steam Electric Power Plants

4.3.2 Water Requirements for Coal Gasification

4.3.3 Water Requirements for Coal Liquef action

4.3.4 Water Requirements for 0 il Shale Development

4.4 INSTITUTIONAL CONSTRAINTS

5.0 AN ASSESSMENT OF REQUIREMENTS FOR DRY COOLING

5.1 INSTALLED CAPACITY BY AGGREGATED SUBAREA 5-1

5.2 REPLACEMENT CAPACITY

$5-6$

5.3 LOAD GROWTH AND REPLACEMENT CAPACITY REQUIREMENTS

5.4 LOCATION OF SYNFUEL PLANTS

5.5 REQUIREMENTS FOR DRY COOLING

5.6 SURVEY: STEAM ELECTRIC POWER PLANT COOLING 5-38

5.6.1 Electric Power Region 22

5.6.2 Electric Power Region 23

5.6.3 Electric Power Region 24

$5-41$

5.6.4 Electric Power Region 26

$5-42$

5.6.5 Electric Power Region 27

$5-43$

5.6.6 Electric Power Region 28 


\section{FIGURES}

Figure

Page

1.1 Distribution of Forecasted Need for Advanced

Cooling: Low Growth Scenario, Power Generation Capacity

$1-8$

1.2 Distribution of Forecasted Need for Advanced

Cooling: Median Growth Scenario, Power Generation

Capacity

1.3 Distribution of Forecasted Need for Advanced

Cooling: High Growth Scenario, Power Generation Capacity

2.1 Location of Major Coal Fields in the Contiguous United States

2.2 Location of $0 i 1$ Shale Reserves in the United States

4.1 Location of Aggregated Subareas (ASA) in the Contiguous United States

5.1 Electric Power Regions in the Contiguous United States 


\section{TABLES}

Table

2.1 Ten Major Coal Producing States (1979)

3.1 Summary of Electrical Energy Growth Scenarios (GWe)

3.2 Summary of Synthetic Fuel Industry Growth Scenarios (Quads)

4.1 Summary of Average Annual Fresh Water Surface Supply and Consumptive Demand (Mgd)

4.2 Water Equivalent Hydrogen Balance Gasification Plant Producing $250 \times 10^{6}$ scf of 303 Btu/scf Gas, Bituminous Coal

4.3 Water Equivalent Hydrogen Balance: Hygas Plant Producing $250 \times 10^{6} \mathrm{scf} /$ day of $969 \mathrm{Btu} / \mathrm{scf}$ Gas, Wyoming Subituminous Coal

5.1 Forecasted Population for each ASA

5.2 Forecasted Electrical Energy Load Growth Requirements (GWe)

5.3 Replacement Capacity Construction Requirement (GWe)

5.4 Capacity Additions: Load Growth and Replacement 2000 to 2020 (GW) Low Growth Scenario

5.5 Capacity Additions: Load Growth and Replacement 2000 to 2020 (GW) Median Growth Scenario

5.6 Capacity Addition: Load Growth and Replacement 2000 to 2020 (GW) High Growth Scenario

5.7 A Summary of Synfuel Facilities (Number of Units)

5.8 A Summary: Advanced Cooling Requirements and Estimated Water Savings (Low Growth Scenario)

5.9 A Summary: Advanced Cooling Requirements and Estimated Water Savings (Median Growth Scenario)

5.10 A Summary: Advanced Cooling Requirements and Estimated Water Savings (High Growth Scenario) 
In 1976, the Hanford Engineering Development Laboratory completed a study on the need for dry cooling. (1) The study examined electric load growth projections through the year 2000 and used fresh water resource limitations as a proxy to overall power plant economics as a means of delineating the. requirements for dry cooling. It was concluded that, "the cooling water supply situation in the United States through the year 2000 is adequate in most areas, but is uncertain over much of the southwest. Limitations on coastal siting, seismic zone constraints, and state constraints on the purchase and transfer of water rights from other uses to cooling supply have the potential of bringing wet/dry or dry cooling into relatively common use in the 1990's."

Over the last few years, projections of future energy use have consistently been reduced. Consistent with this trend, electrical load growth requirements have also been reduced. In terms of water resource requirements, a report recently issued by the General Accounting office concludes that an adequate water supply is available to support energy development through at least the year 2000. (2) The conclusion is predicated upon the fact that reduced energy growth rates, coupled with practices of water conservation, have eased the overall burden, permitting the limited water resource to support energy development goals through the turn of the century. Over the long term, however, the development of energy resources will require the commitment of large quantities of water resources. Furthermore, if the commitment is imposed upon the water resources in a water-short region, some compensation or adjustment in the overall management of the resource must be accommodated. Therefore, in terms of planning, it seems prudent to assume that a reduced energy growth simply shifts the date when advanced cooling will be needed. It does not el iminate the need.

A scenario is proposed which assumes that over the next few decades (40 to 50 years) a steady transition or evolution from a primary dependence upon $0 i 1$ and gas to a more general dependence upon oil and gas, electricity, and 
synthetic liquid and gaseous fuels will occur. It is further assumed that liquid fuels, first $0 i 1$ and gas and subsequently synthetic liquid fuels, will gradually become dedicated for use in the transportation sector of our economy. As a result, the use of electricity in the residential, commercial and industrial sectors of our economy will increase to fill the need vacated by liquid fuels.

It is assumed that this transition will be characterized by an increase in the number of centralized electrical power plants and energy resource development centers such as synfuel production facilities. The coal and oil shale resources of the country will be developed and their use gradually substituted for conventional forms of hydrocarbons.

Based upon present day technology, it is further assumed that these facilities, i.e., centralized electrical power plants and synthetic fuel development centers, will require the use of plant cooling facilities. In the case of steam-electric power plants, imposing today's plant efficiencies, approximately two-thirds of the energy input is lost to the environment and typically all or most of this loss is handled by the plant cooling systems. By comparison, in the production of synthetic fuels it is estimated that effectively less than one half of the energy will be handled by the plant cooling systems.

Briefly reviewing, steam-electric power plants have traditionally used the conventional Rankine power cycle. Frequently preheaters, reheaters, and bottoming cycles have been added as a means of increasing the overall efficiency of the system. Basically, however, all steam-electric power plant systems are equipped with low back-pressure steam turbines, which nominally limit the vapor/condensate pressure to $5 \mathrm{in}$. Hga, or approximately $134^{\circ} \mathrm{F}$.

As a result of environmental legislation introduced during the late 1960's and early 1970's and promulgated during the mid 1970's, a trend toward the increased use of wet evaporative cooling towers has persisted. Ironically, 
evaporative cooling towers have several environmental drawbacks, not the least of which is the heavy demand $p$ laced upon water resources in the form of consumptive water demand. Comparatively speaking, the consumptive water requirements associated with wet evaporative towers are 300 to $500 \%$ higher than the evaporative losses normally associated with once-through cooling.

Evaporative cooling towers are large consumers of water. The evaporative losses associated with operating a 1000-MWe nuclear power plant equipped with a wet evaporative cooling tower are roughly equivalent to the water needs of a municipality with a population of 100,000. Obviously, in geographical areas which experience a water shortage or have a limited water supply, the demands of a large evaporative cooling system are significant. For these situations, an advanced form of cooling technology which relies less upon the mechanism of evaporative heat transfer would be extremely desirable.

Technologically, there is nothing to prevent the use of dry cooling. High back pressure turbine designs are available that would allow operation of steam turbines up to $15 \mathrm{in.} \mathrm{Hga.} \mathrm{Mitigating} \mathrm{against} \mathrm{the} \mathrm{use} \mathrm{of} \mathrm{dry} \mathrm{cooling}$ are water resource and power plant economics. Higher costs and decreased performance of power generation systems have in the past been the primary deterrent to selecting dry or near-dry cooling systems. Over the years, economic studies have been performed which relate the cost of water to the cost of constructing and operating dry or wet/dry hybrid systems. In terms of comparative economics, the cost of water would have to approach $\$ 50$ per 1000 gallons before a totally dry cooled system could be justified. (3) on the other hand, as the cost of water approaches $\$ 1.00$ per 1000 gallons, a $50 \%$ peak-shaved dry/wet cooling system was found to be competitive with a totally wet evaporative system. (4) Generally speaking, the busbar cost of electrical energy generated from Rankine cycle thermal power plants equipped with non-evaporative cooling systems was found to be $10 \%$ to $23 \%$ higher than the cost associated with wet evaporative cooling systems. 
With respect to today's economy and environmental conditions, these statistics appear to be somewhat tenuous. Approval of power plant cooling system designs have caused extensive delays at several power plants, e.g., Turkey Point, Seabrook, etc. Although there is no guarantee that the use of a dry cooling system would totally el iminate the delays, it seems reasonable to assume that the use of a dry system would encounter less environmental criticism, since an environmental interface, i.e., the need for a power plant cooling water intake and discharge structure is eliminated. As a result, the net effect, economically speaking, would be to reduce the busbar cost differential associated with generating electricity to something less than the 10 to $23 \%$ difference discussed in the previous paragraph.

It is assumed that a transition in cooling technology will occur in the future. The trend will be initiated in water-short areas. A logical progression or transition will occur, i.e., totally wet, to wet/dry, to totally dry. Furthermore, it is suggested that this transition has been initiated in response to water availability constraints and that power plants constructed after the turn of the century will reflect an increasing trend toward the use of advanced cooling configurations.

\section{$1.1 \quad$ PURPOSE AND SCOPE}

The purpose of this study was to examine the need for an advanced cooling technology which conserves water by relying less upon the mechanism of evaporative cooling. The approach selected used data on water resource supply and demand characteristics as a basis for quantifying the requirement for advanced cooling. The approach was selected over the more traditional approach which employs the use of power plant economics for the following reasons: 1) the market for water is poorly defined; and 2) a price or cost of water is perhaps a poor measure of its value to society.

Traditionally, agriculture has been the primary user of water. As a general rule, agriculture cannot compete with energy when it comes to purchasing water. Furthermore, the guiding principle behind the development of 
riparian water rights practiced almost exclusively in the eastern sector of the country guarantees and assures the reasonable use of water at no cost.

In most western states, on the other hand, the threat of water shortages was apparent from the time of the earliest settlements. Major users of water in this region, moreover, involve transport of water away from streams for consumptive use (e.g., irrigation canals). In this atmosphere, most western states have adopted appropriative rights doctrines involving a "first come, first served" rights philosophy. In recent years, as local or regional shortages have become more apparent, several states have modified this doctrine to include institutional prioritization of uses, with priority rights conferred on those uses ajudged most beneficial. Typically, the prioritization favors uses such as irrigation and municipal water supplies.

In states maintaining "orthodox" appropriative rights doctrines, it may be feasible for a prospective user such as a power utility to obtain water rights by purchasing those of others (usualiy agricultural rights are involved). If water rights are legally prioritized, however, this may be difficult or even impossible.

In terms of water use, the ultimate limiting constraint is consumptive use. In this study, the annual average supply and average annual consumptive use were used as a basis for determining the need for advanced cooling technology. The criterion that was used assumed that when the average annual consumptive demand for fresh water equaled or exceeded $50 \%$ of the average annual supply of fresh surface water, advanced cooling would be required.

One might argue that since there are regions in the country where this condition already exists and has existed for some time, and the use of advanced cooling technology is not commonly practiced that the criterion is unacceptable. However, in most of these regions, first signs in the form of water reclamation, wet/dry towers, etc. are beginning to surface. 


\subsection{SUMMARY AND CONCLUSIONS}

An assessment was made of the impact of projected growth in electrical generation and synthetic fuels production over a 20-year period, from the year 2000 to 2020, on water supplies in the continental United States. Based on this assessment, an evaluation was made of the need for dry cooling technology in areas where water shortages are projected.

Three electrical energy growth scenarios were prepared: a high growth scenario which assumes a growth of installed capacity equal to $550 \mathrm{GW}$ for the contiguous United States during the 20-year time period; a medium growth scenario which assumes a growth in capacity of $300 \mathrm{GW}$ during the study period; and a low growth scenario which assumes a growth of $175 \mathrm{GW}$ over this period.

The installed capacity was disaggregated into forecasted growth in each of 99 subareas within the contiguous United States using forecasted population change as a basis for disaggregation. Replacement capacity requirements, forecasted to be $360 \mathrm{GW}$ over the 20-year forecast period, were superimposed upon load growth demands and were arbitrarily assigned to the subareas in which the capacity had been previously located.

For the high energy growth scenario, 126 to $196 \mathrm{GW}$ of electric generating capacity constructed during the 20-year forecast period will require advanced cooling technology. The total number of synfuel facilities requiring advanced cooling is forecasted to be 60 units; for purposes of analysis, each unit synfuel facility was assigned a capacity of $250 \times 10^{9}$ Btu's per day.

For the medium growth scenario, the capacity addition requiring advanced cooling is forecasted to range from 74 to $144 \mathrm{GW}$. The total number of synfuel facilities requiring advanced cooling is forecasted to be 38 . 
For the low growth scenario, the capacity of steam electric generating facilities requiring advanced cooling ranges from 40 to $110 \mathrm{GW}$. For this scenario, 14 facilities, each with a capacity of $250 \times 10^{9}$ Btu's per day are forecasted to require advanced cooling.

Figures $1.1,1.2$ and 1.3, display the areal distribution of advanced cooling requirements associated with forecasted electrical energy load growth and synfuel industry requirements. The distribution of advanced cooling facilities is presented in terms of Aggregated Subareas. Figure 1.1 shows the cooling requirements for the low growth scenario, Figure 1.2 shows requirements for the median growth scenario, and Figure 1.3 shows those for the high growth scenarios.

Approximately $95 \%$ of the advanced cooling requirement will be located in the arid southwest. Furthermore, approximately $50 \%$ of the demand for advanced cooling of steam electric generating facilities will be located in the States of California and Texas. Synfuel coal facilities located in the Powder River Basin (Aggregated Subarea 1004) and oil shale facilities located in the Green River Basin (Aggregated Subarea 1401) are also forecasted to require advanced cooling. 


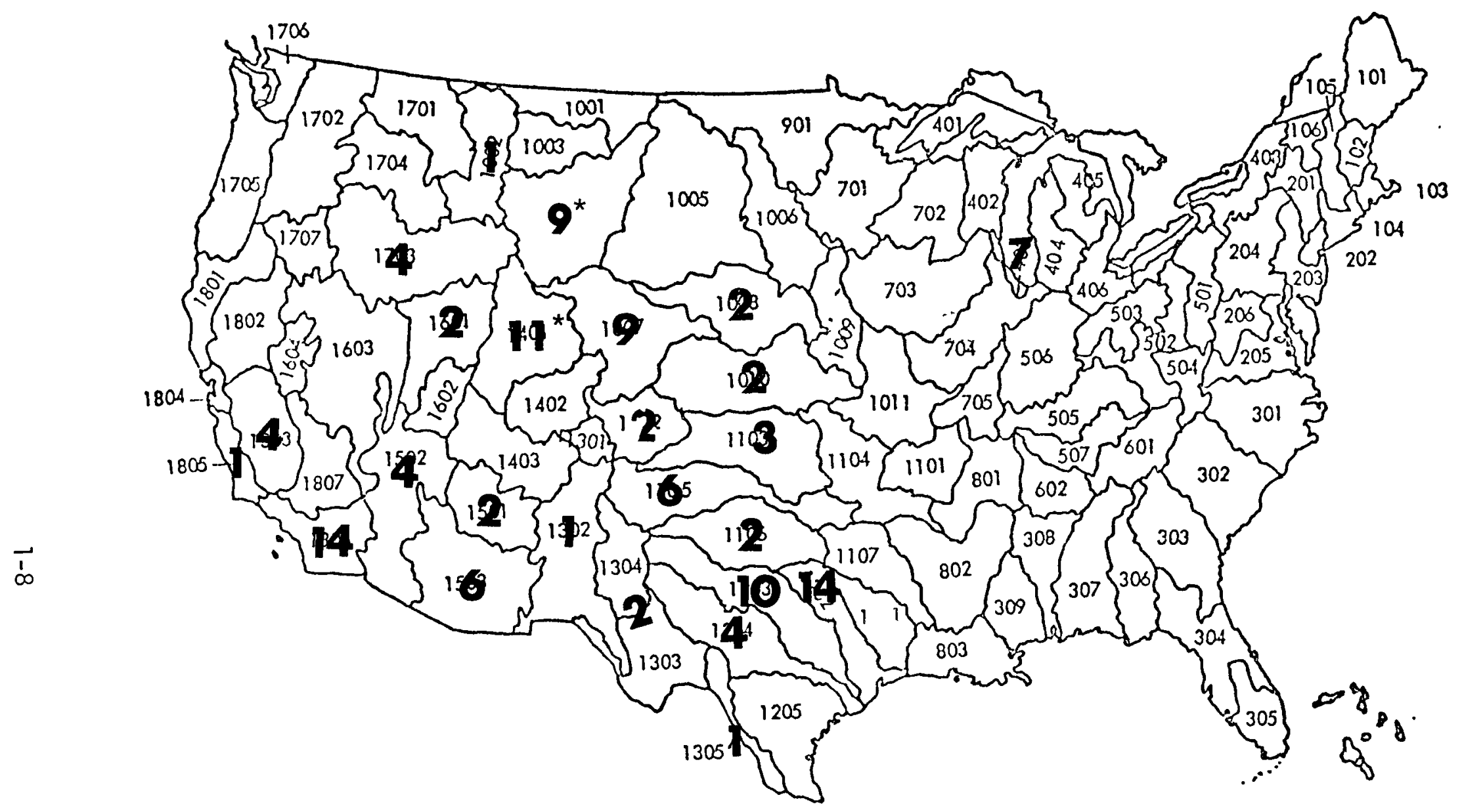

Note: Total number of facilities sited in each Aggregated Subarea (ASA) shown in bold figures..

* Number represents total numbers of $250 \times 10^{9}$ Btu/day synfuel facilities.

FIGURE 1.1. Distribution of Forecasted Need for Advanced Cooling: Low Growth Scenario, Power Generation Capacity (GWe). 


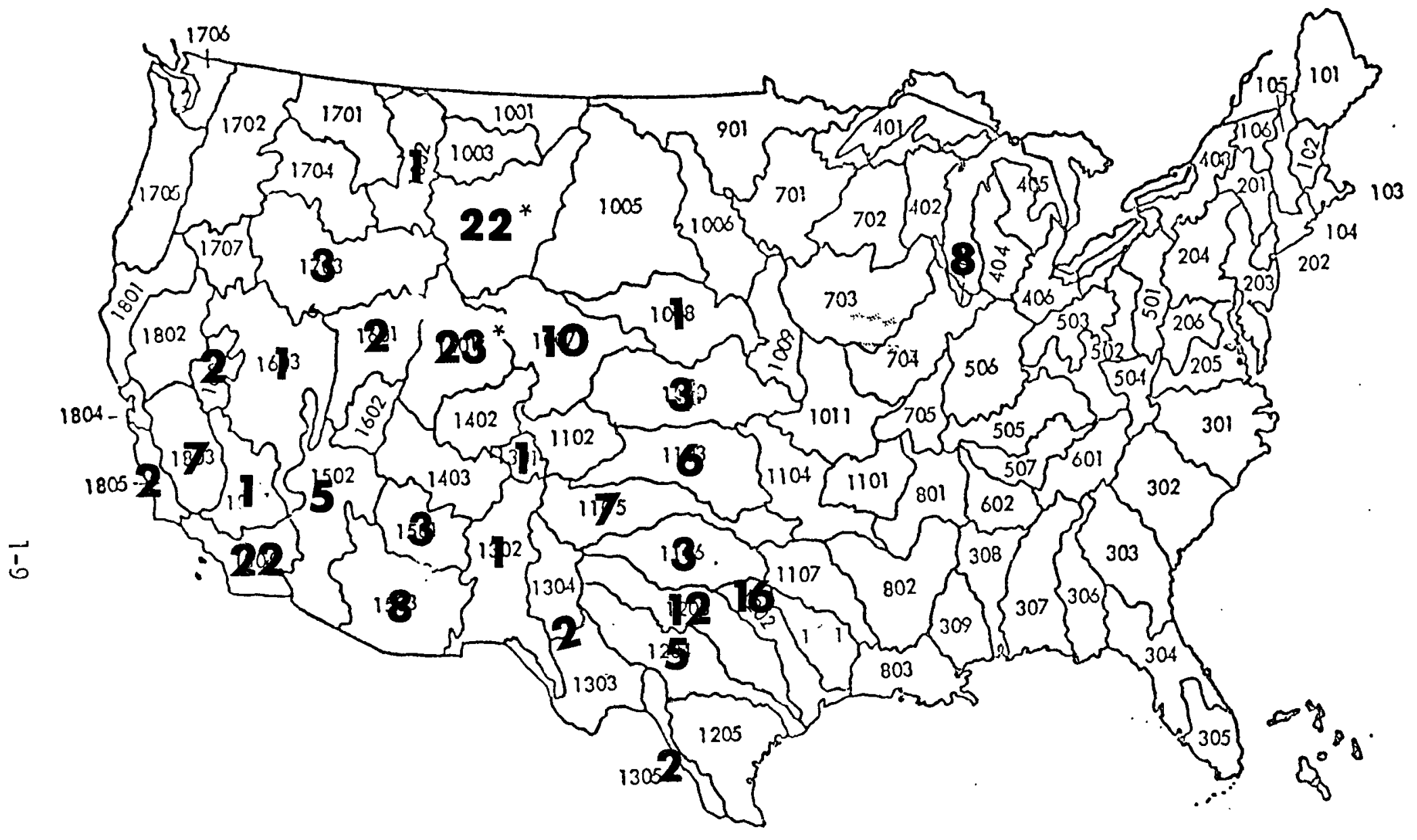

Note: Total number of facilities sited in each Aggregated Subarea (ASA) shown in bold figures.

${ }^{*}$ Number represents total number of $250 \times 10^{9}$ Btu/day synfuel facilities.

FIGURE 1.2. Distribution of Forecasted Need for Advanced Cooling: Median Growth Scenario, Power Generation Capacity (GWe). 


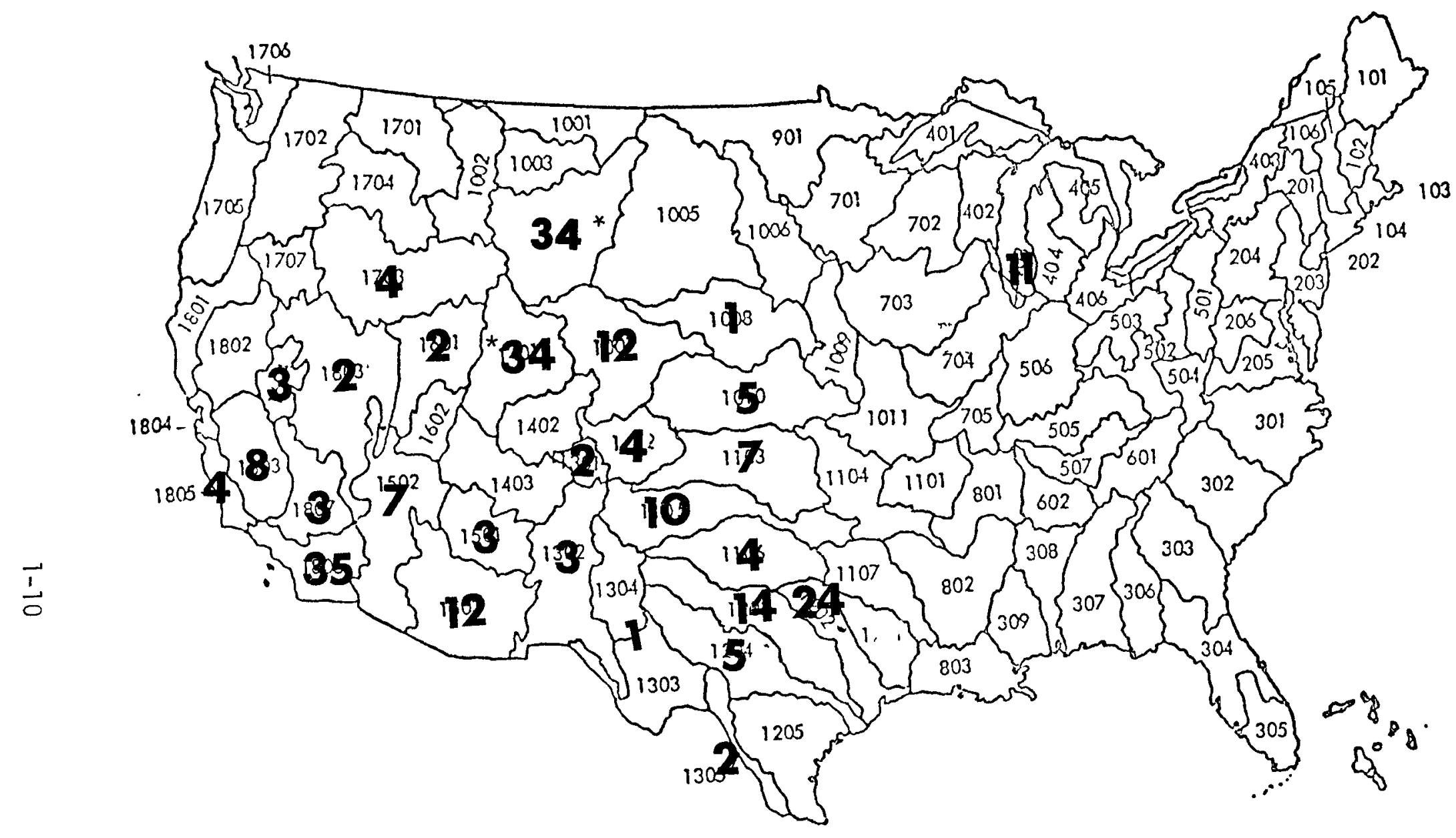

Note: Total number of facilities sited in each Aggregated Subarea (ASA) shown in bold figures.

* Number represents total number of $250 \times 10^{9}$ Btu/day synfuel facilities.

FIGURE 1.3. Distribution of Forecasted Need for Advanced Cooling: High Growth Scenario, Power Generation Capacity (GWe). 
Over the last fifty years, the world developed a primary dependence upon the use of $0 i 1$ and gas to satisfy its energy needs. However, the world's oil and gas reserves are becoming depleted; consequently, substitute forms of energy must be developed. It is generally agreed that over the next fifty years, a transition or shift from a primary dependence upon the use of oil and gas to a more balanced or distributed supply, i.e., coal, nuclear, oil shale, solar, etc. will occur.

Shifts in energy supply to satisfy growth in energy demand will likely occur. Electricity is forecasted to satisfy much of the increase in end use demand.

In support of energy demand in the transportation sector, a synthet ic fuel industry is forecasted to emerge at the turn of the century. The use of synthetic fuels is forecasted to increase over the time period 2000-2020.

\subsection{ENERGY USE BY ECONOMIC SECTORS}

The Nation's energy system consists of four major components of use, industrial, residential, commercial, and transportation. During 1980, the industrial sector consumed 30.1 quads of energy. Electricity sales to the industrial sector equaled 2.8 quads. In the residential and commercial sectors, 27.0 quads of energy were consumed in 1980. Electrical sales in the residential and commercial sector equaled 4.3 quads during 1980 . In the transportation sector, approximately 19.0 quads of energy were consumed during 1980. Electricity sales amounted to less than 0.01 quad in the transportation sector. (5)

The industrial fuel $\mathrm{mix}$ is forecasted to change. During 1978, approximately $12 \%$ of the energy consumed by industry was supplied by electricity. In 1995, electricity is forcasted to provide approximately $20 \%$ of the energy used by industry. (6) The growth in electrical energy usage is forecasted to be approximately $3 \%$ per year through 1995 . 
The net energy consumed by the residential and commercial sectors of the economy is forecasted to remain essentially constant through the year 2000. The fuel mix is forecasted to change. The effect of rising energy cost will have a tendency to stem the increase in electrical energy use; however, within both the residential and commercial sectors, electricity's share of the market is forecasted to increase from approximately $22 \%$ in 1978 to $31 \%$ in 1995, an average annual increase of $2 \%$. ${ }^{(6)}$

Through the year 2000, the transportation sector is forecasted to remain primarily dependent on the use of liquid fuels derived from petroleum. Petroleum use is predicted to become more efficient, and a significant shift from gasoline to more efficient diesel fuel is forecasted. The use of substitute energy sources such as electricity and hydrogen fuels for vehicles prior to the year 2000 is assumed not to have a significant impact on energy use... "The projected transportation share of total U.S. oil use increases from $53 \%$ in 1978 to $63 \%$ in $1995 . . . "(6)$

In summary, a reaggregation of energy use by economic sectors suggests the following:

Through the year 2000, it is estimated that coal, oil and gas will supply approximately $80 \%$ of the energy resource requirement. The remaining $20 \%$ will be supplied by nuclear, hydroelectric, and other forms of renewable energy. It is estimated that approximately 70 to 80 quads of energy will be consumed for specific end use application in the year 2000. Electrical energy is forecasted to supply between 10 and 14.3 quads of the end use demand. By comparison, during 1980, 24.8 quads of energy were used to supply an electrical energy demand of 2.1 trillion kWh (7.17 quads). The average annual growth rate in usage of electrical energy is forecasted to range from 1.7 to $3.5 \%$. 


\subsection{ELECTRICAL ENERGY DEMAND FORECAST}

In this study, the forecast horizon extends over a forty year period (1980 to 2020). Reflecting back, during the last forty years (1940 to 1980), the United States experienced a period of tremendous technological advancement. In terms of electrical energy demand, the United States experienced a period of rapid electrification. By comparison, usage of electrical energy during 1940 was less than $10 \%$ of the electrical energy usage in 1980. Furthermore, over the last twenty years, electrical energy usage measured in terms of kilowatt-hours sold increased by a factor of three. During 1980, approximately 2.1 trillion kWh of electrical energy were sold by electrical utilities. The net production of electricity was 2.285 trillion kWh.

Forecasting the need for electrical energy is extremely subjective and although a number of analytical techniques have been developed over the last few years to assist the planner, the fact remains that the future is unknown and no one should be under the illusion that the future is deterministic. Mathematical models are extremely useful in sorting out contributing cause and effect relationships; however, institutional, environmental, and social factors exercise a "de facto" control over the application and use of technology which cannot be totally rationalized. As a result, human judgment will continue to play an important role in forecasting energy use.

\subsubsection{Electrical Energy Growth Forecasts (1980 - 2000)}

Forecasts of electrical energy requirements have reflected a downward trend over the last five years. Forecasts during the early and mid 1970's were strongly influenced by the growth in electrical energy usage which occurred during the previous decade. During the 1960's, the average annual growth rate in electrical energy usage was approximately $7 \% .(7)$

During the 1970's, the demand for electrical energy increased at an annual rate of $5 \%$. In 1970, the sales of electrical energy were $1.38 \times 10^{12} \mathrm{kWh}$. 
In 1980 electrical energy sales totaled $2.1 \times 10^{12} \mathrm{kWh}$. Over the last five years of this decade, the sales of electrical energy increased at an average annual rate of $4 \%$.

The end use consumption of electrical energy is forecasted to be 11.3 quads or $3.3 \times 10^{12} \mathrm{kWh}$ in the year 1995 for the median growth scenario in Reference 6 . A mid range electrical energy usage of 12.3 quads in the year 2000 is forecasted in Reference 6 . A recently released national energy plan (NEP III), (8) forecasts 12.3 quads of electrical energy delivered in the year 2000 . The 12.3 quads is equivalent to $3.6 \times 10^{12} \mathrm{kWh}$.

A recently released Electric Power Research Institute publication selects three growth rate scenarios for planning purposes, i.e., low growth of $2.5 \%$ a year, an intermediate growth of $2.9 \%$ a year and a high growth of $3.5 \%$ a year. (9) Although EPRI's planning is based upon the case of intermediate growth, which is expected to include a significant level of conservation (approximately 20\%), ....... "prudent projections suggest that the utility industry should expect demand to grow in energy generation from the present level of $2.4 \times 10^{12} \mathrm{kWh}$ to $5.9 \times 10^{12} \mathrm{kWh}$ in the year 2000 ." The $5.9 \times 10^{12} \mathrm{kWh}$ forecasted generation translates to approximately $5.3 \times 10^{12} \mathrm{kWh}$ sales (after transmission losses), or 15.5 quads. A recent article in Electrical World forecasts total sales of electrical energy to be approximately $4.0 \times 10^{12} \mathrm{kWh}$ in the year 2000. (10)

In summary, estimates of future electrical energy demand vary widely. Different assumptions lead to different projections. Although the demand for electrical energy in all sectors of the economy is anticipated to grow over the next 20 years, it is assumed that the growth rate in electrical energy consumption will be less than the growth rate planned during the $1970^{\prime} \mathrm{s}$ and will average between $3 \%$ and $4 \%$ per annum during the 1980 's and $2 \%$ and $3 \%$ during the 1990's. Using the data discussed previously, the electrical energy usage or consumption in the year 2000 is forecasted to range from 3.0 to $4.2 \times 10^{12} \mathrm{kWh}$. Three scenarios which forecast an electrical 
usage of $3.0 \times 10^{12} \mathrm{kWh}\left(\right.$ low), $3.6 \times 10^{12} \mathrm{kWh}$ (median) and $4.2 \times 10^{12} \mathrm{kWh}$ (high) were assumed and used in the analysis herein. The median forcast agrees with NEP-III.

\subsubsection{Electrical Energy Growth Forecasts (2000 - 2020)}

Recent forecasts on post-year 2000 demands for electrical energy are limited. The Third National Energy Plan prepared and presented to Congress during the summer of 1981 did not address forecasted energy use beyond the year 2000 . Needless to say, projections of electrical energy demand after the year 2000 are highly speculative.

The 1980 annual report to Congress forecasts a mid-range usage of 17.9 quads or $5.24 \times 10^{12} \mathrm{kWh}$ of electrical energy sales in the year $2020 .{ }^{(6)}$ A range in electrical energy usage of 17.3 to 18.4 quads is forecasted in Reference 6 . A recent report by the Electric Power Research Institute forecasts an electrical energy demand of $11 \times 10^{12} \mathrm{kWh}$ in the year 2020. (9) The forecast by the Electric Power Research Institute suggests an electrical energy usage in the year 2020 twice the forecast proposed by DOE/EIA in its 1980 annual report to Congress. (6)

An increase in the demand for electrical energy from 3.6 trillion $\mathrm{kWh}$ in the year 2000 to 5.2 trillion $\mathrm{kWh}$ in the year 2020 reflects an annual average growth rate of approximately $2 \%$. An increase in the demand for electrical energy from 4.2 trillion $\mathrm{kWh}$ in the year 2000 to 11 trillion $\mathrm{kWh}$ in the year 2020 reflects an annual average growth rate of approximately $5 \%$.

A median usage of 5.24 trillion kWh, taken from the 1980 Report to Congress, ${ }^{(6)}$ was assumed for purposes of analysis. To bracket the analysis, a high electrical energy usage of 7.1 trillion kWh and a low electrical energy usage of 4.2 trillion $\mathrm{kWh}$ were assumed. 


\subsection{ENERGY FROM SYNTHETIC FUELS}

In the future the United States will rely less heavily upon petroleum resources such as $0 i l$ and gas. Generally speaking, a moderate increase in the demand for liquid petroleum products with a gradual shift or increase in the use of synthetic fuels to fill the void created through the depletion of the world's oil reserves is assumed to occur.

Synthetic fuels offer a long-term means to supplement and perhaps eventually replace diminishing oil and natural gas supplies. Synthetic fuels in the form of gas and liquids produced from coals are looked upon as the technology most likely to fill the void that may arise. Another viable option which can be used to fill the energy need created through the depletion of the world's oil reserves is oil shale. In the western United States vast oil shale reserves exist. It is estimated that more than 360 billion barrels equivalent of oil shale exist in the United States. About $80 \%$ of the reserve is located on federally owned 1 and in Colorado, Utah, and Wyoming.

\subsubsection{Synthetic Fuel From Coal}

As shown in Figure 2.1, coal is located in all major regions of the United States. Over the years, the Appalachian Mountain coal reserve has been the primary region for producing domestic coal. More recently, there has been a shift toward developing coal resources in the western United States. Table 2.1 lists the ten major coal producing states in 1979. By comparison, the six leading coal producing states in 1975 were Kentucky, West Virginia, Pennsyivania, Illinois, Ohio and Virginia. It is generally thought that the development of the coal-supported synfuel industry will be widespread, with major location of development centered in the northern Appalachian coal fields, midwestern or interior coal basins, predominately in the states of Illinois and western Kentucky, and the northwestern coal region of the northern Great Plains in the states of 


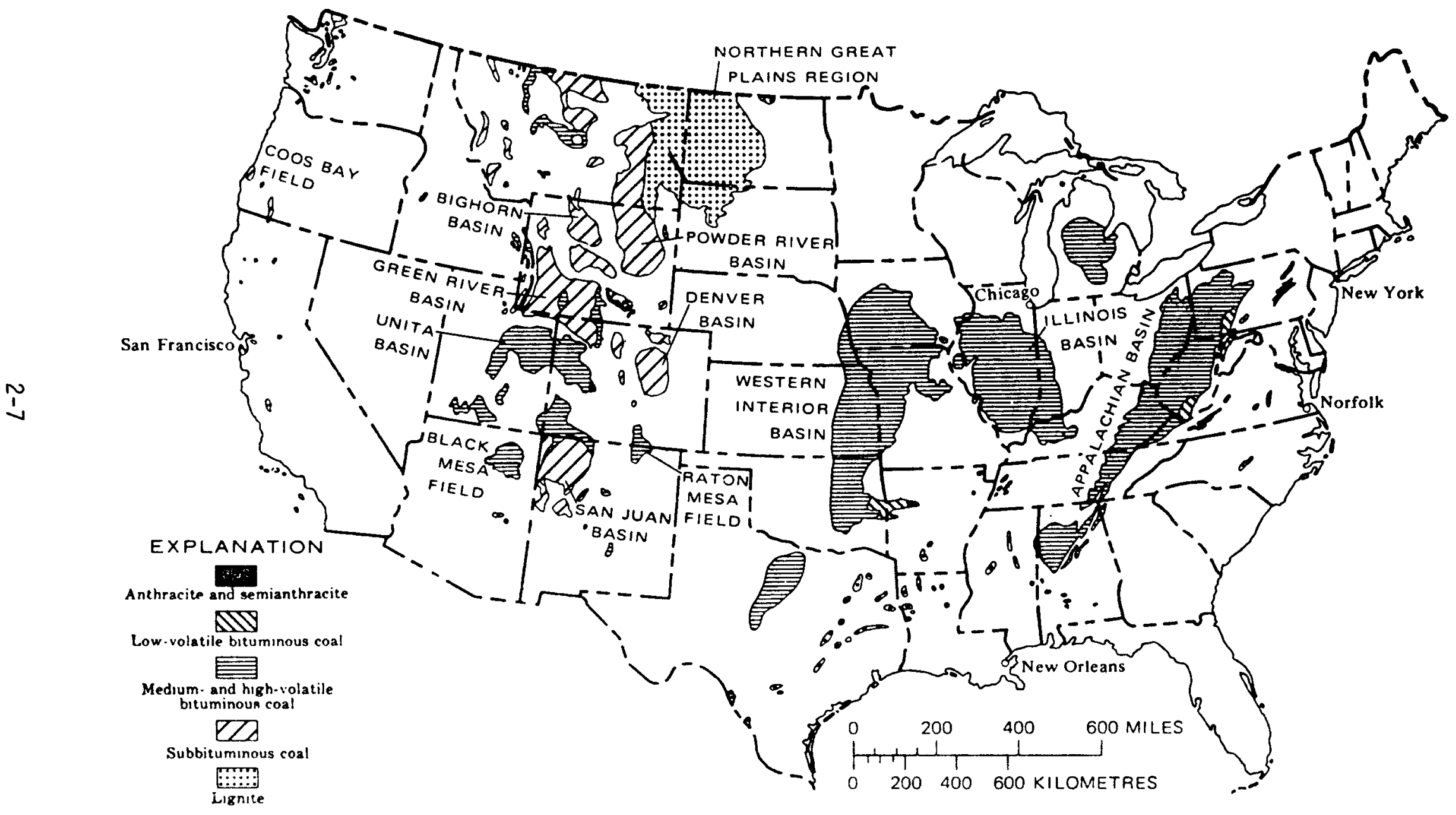

FIGURE 2.1. Location of Major Coal Fields in the Contiguous United States. 
TABLE 2.1

TEN MAJOR COAL PRODUCING STATES (1979)

Production

State

(million short tons)

Kentucky

143

West Virginia

112

Pennsylvania

93

Illinois

58

Wyoming

58

Ohio

43

Montana

39

Virginia

35

Indiana

28

A l abama

24 
North Dakota, Montana, and Wyoming. In this study it was assumed that synfuel derived from coal would range from 2-4 quads in the year 2000 and from 4-8 quads in the year 2020 .

\subsubsection{Synthetic Fuel from 0il Shale}

Geologic formations containing vast quantities of oil shale are located in the upper Colorado River Basin. The Green River formation located in southwestern Wyoming is the geologic resource containing the most abundant quantity of oil shale in the United States. (11) It is estimated that the Green River Formation contains more than three trillion barrels of oil equivalent as oil shale reserves equivalent to 54 billion barrels of syncrude. The oil shale formations located in the Piceance Bas in of Colorado and the Uinta Basin of Utah are considered to be the most economically recoverable portion of the resource. The locations of the major oil shale deposits are shown in Figure 2.2.

As mentioned previously, the tremendous oil reserves contained in oil shale formation are concentrated in a small area of the United States. As a result, an intensive development of the shale resource could easily result in an appreciable degradation to the local environment. Both air quality and water availability are of paramount concern and could ultimately limit the development of oil shale resources to a small fraction of their potential. In this study it was assumed that synthetic fuel derived from oil shale development would range from 1 to 3 million barrels per day in the year 2000 and from 3 to 5 million barrels per day in the year 2020 . 


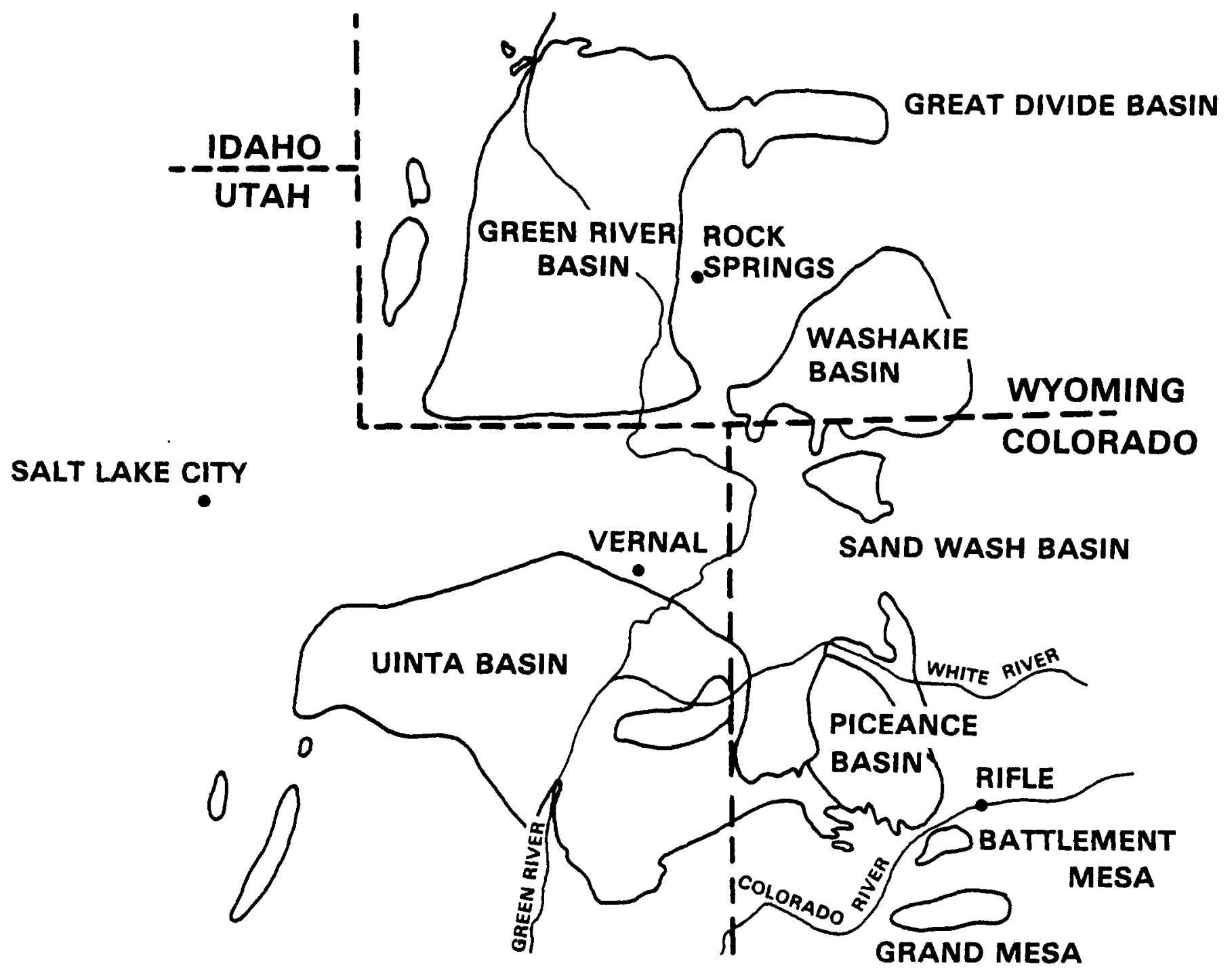

HEDL 8103-144.2

FIGURE 2.2. Location of 0 il Shale Reserves in the United States. 
A discussion of forecasted installed electrical energy capacity and synfuel facilities is provided in this section of the report.

\subsection{FORECASTS OF INSTALLED ELECTRICAL GENERATION CAPACITY}

A demand (usage) and supply (installed capacity) relationship can be established by specifying three factors, reserve margin, load factor, and transmission loss. Briefly reviewing, a reserve margin is designed into a power system for the purpose of assurance, i.e., a guaranteed reliable supply. A load factor is used to relate the average and peak demands in a power supply grid, and the transmission loss results from the conveyance of electrical energy from the point of generation to the point of usage.

Historically, a $30 \%$ reserve margin has typically been assumed. Operational experience through the 1960's suggested that a reserve margin of 17 to $20 \%$ would be acceptable. However, over the last few years, trends have emerged which could significantly impact what might be considered an adequate reserve margin in the future. Over the last few years, utilities have generally installed large generating units to take advantage of the overall economics associated with large sizes, i.e., economy of scale. These larger units have experienced higher outage rates than smaller sized units. Obviously, if large units are not available, their impact on the overall operation is more significant than if a smaller size unit were not available. This suggests that if the trend toward constructing large sized power plants continues, either the reserve margin built into the electrical power grid should remain at approximately $30 \%$ or the reliability of the large sized power plants must improve.

In addition to assurance, the reserve margin has become a necessity in the planning process. Over the last decade, construction lead times increased substantially. At the present time, construction lead times average 10 to 12 
years for nuclear power plants. Assuming a load growth of $3 \%$ with these lead times, it would seem prudent that at any point in time a reserve margin of about $30 \%$ should be maintained.

Without some means of storing electrical energy, the generating capacity of a power grid must be sized to satisfy the peak demand. It is anticipated that the effect of present load leveling programs, using both storage technology and variable rate structuring, will impact future peak load requirements. Load leveling is presently being encouraged and it is anticipated that the trend will continue and will be reinforced through institutional control and technological innovation.

Historically, load factors have ranged from 0.5 to 0.65 , suggesting that the peak demand is approximately twice the average demand. Depending upon the region of the country being considered, the maximum or peak demand could occur in either the summer or winter. In the aggregate, the United States is characterized by a summer peak. During 1979 the summer peak demand was $401 \mathrm{MW}$. (14) This compares with an average demand of $236 \mathrm{MW}$ during 1979 and a load factor of .59 .

As mentioned previously, transmission losses result during the conveyance of electrical energy from the point of generation to the point of use. During recent years, the differences between the level of production and the level of consumption or sales has averaged approximately $10 \%$.

\subsubsection{Electrical Energy Capacity Scenarios (1980 - 2000)}

Three scenarios were prepared for purposes of analyzing future growths in the installed electrical generating capacity. A low growth scenario was prepared which assumed a modest growth in electrical energy usage. Electrical energy sales in the year 2000 were assumed to be 3.0 trillion $\mathrm{kWh}$. Assuming a reserve capacity factor of 0.3 , a peak load factor of 0.6 , and a 1 ine loss factor of $10 \%$, the installed capacity requirement in the year 2000 is estimated to be 825 GWe. A median growth scenario was defined and 
patterned after the aggregate electrical energy usage of 3.6 trillion $\mathrm{kWh}$ forecasted for the year 2000, in both the U.S. Department of Energy's 1980 Report to Congress ${ }^{(6)}$ and the more recently issued Third National Energy Plan. (8) Assuming a reserve capacity factor of $30 \%$, a peak load factor of 0.6 and a line loss factor of $10 \%$, the installed capacity requirement in the year 2000 is estimated to be 950 GWe. A high growth scenario which assumes an electrical energy usage (sales) of 4.2 trillion $\mathrm{kWh}$ in the year 2000 was included for purposes of comparison. A usage of 4.2 trillion kWh in the year 2000 assumes an average annual growth in energy usage of 3.3\% through the year 2000 which is lower than the electrical energy growth rate during the 1970's. Again, assuming a reserve capacity factor requirement of $30 \%$, a peak load factor of .6 and a line loss factor of $10 \%$, the installed generating capacity requirement in the year 2000 is forecasted to be approximately 1150 GWe.

The median growth scenario was compared with data contained in recently issued reports on planned electrical energy capacity addition forecasted for the 1980 's. $(12,13)$ Based upon data received from the nine regional Electrical Reliability Councils in the U.S., the generating capacity during the summer of 1989 is estimated to be $778 \mathrm{GW}$. This is an increase of $234 \mathrm{GW}$ over the summer 1979 generating capacity of $544 \mathrm{GW}$. An extrapolation of this growth to the year 2000 suggests an installed capacity of 1000 GW which is reasonably consistent with the forecast of $950 \mathrm{GW}$ derived from electrical energy use requirements. As a further check; an installed capacity requirement of 937 GWe in the year 2000 is forecasted in Reference 10 .

\subsubsection{Electrical Energy Capacity Scenarios (2000 - 2020)}

After the year 2000, there is a potential for profound changes in the basic structure of the national generating system and supply technology. For example, if over the next 20 years, power plant economics are characterized by rigorous conservation and storage efforts, requirements for large central power stations could be substantially reduced. On the other hand, if the overall economics associated with steam electric power plant construction 
improve, a substantial increase over the present trend in numbers of power plants constructed could emerge. As a result, three scenarios were examined.

A median electrical energy installed capacity scenario was established from the electrical energy usage of 5.24 trillion $\mathrm{kWh}$ in the year 2020 forecasted in Reference 6 . A reserve capacity requirement of $30 \%$ and a load factor of 0.675 were assumed. A line loss factor of $10 \%$ consistent with present day technology, was also assumed. Using these assumptions, an installed electrical energy capacity requirement of 1250 GWe was forecasted for the median electrical energy growth scenario in the year 2020 .

An electrical energy usage of 4.2 trillion kWh was assumed for the low growth scenario. This scenario assumes limited growth in the overall aggregate electrical generating capacity of the United States. Assigning a reserve capacity factor of $30 \%$ a load factor of 0.675 , and a line loss factor of $10 \%$, the installed electrical generating capacity for the contiguous United States in the year 2020 is forecasted to be 1000 GWe. The growth in installed capacity is estimated to be $175 \mathrm{GW}$ over the 20-year time period 2000 to 2020 .

An electrical energy usage of 7.1 trillion $\mathrm{kWh}$ was assumed for the high growth scenario. For this scenario, the installed capacity in the year 2020 is forecasted to be 1700 GWe. Comparatively speaking, a growth of 550 GWe over the time period 2000 to 2020 equates to a modest annual compound growth rate factor of approximately $2 \%$.

A summary of the installed electrical generation capacity scenarios used in the analysis is provided in Table 3.1 .

\subsection{FORECAST OF SYNFUEL PLANTS}

The synthetic fuel technology considered in the analysis included the conversion of coal to gaseous and liquid forms, and the conversion of oil shale 
TABLE 3.1

SUMMARY OF ELECTRICAL ENERGY GROWTH SCENARIOS (GWe)

\begin{tabular}{lrrr} 
& \multicolumn{3}{c}{ Year } \\
High & $\frac{1980}{600}$ & $\underline{2000}$ & $\underline{2020}$ \\
Median & 600 & 1150 & 1700 \\
Low & 600 & 950 & 1250
\end{tabular}


into clean liquid fuels. Standard size plants of $250 \times 10^{6}$ standard cubic feet per day for gaseous products and 50,000 barrels per day for liquid products were assumed. Furthermore, it was assumed that each type of plant produced an equivalent $250 \times 10^{9}$ Btu per day (product) of energy.

Three scenarios were prepared for purposes of analyzing future growth requirements associated with the development of a synthet ic fuel industry. A low growth scenario, which assumed a production equivalent of 4 quads in the year 2000 and 8 quads in the year 2020; a median growth scenario, which assumed 6 quads in the year 2000 and 12 quads in the year 2020; and a high growth scenario, which assumed 8 quads of energy in the year 2000 and 16 quads of energy in the year 2020. Parametrically, this represents a range of 12 quads of synfuel capability which can be examined between the three scenarios. These scenarios are summarized in Table 3.2.

Using the basic plant size data described previously and the data on energy growth provided in Table 3.2, it was calculated that approximately fifteen plants would be required to produce a quad of energy. Therefore, for the low growth scenario, a total of 60 synfuel facilities were calculated to be constructed by the year 2000 and 120 synfuel facilities will be constructed by the year 2020. For the high energy growth scenario, the corresponding number of plants was calculated to be approximately 120 in the year 2000 and 240 in the year 2020 .

TABLE 3.2

SUMMARY OF SYNTHETIC FUEL INDUSTRY GROWTH SCENARIOS (QUADS)

\begin{tabular}{lccc} 
& \multicolumn{3}{c}{ Year } \\
Median & $\underline{1980}$ & $\underline{2000}$ & $\underline{2020}$ \\
High & 0 & 8 & 16 \\
Median & 0 & 6 & 12 \\
Low & 0 & 4 & 8
\end{tabular}


As a nation, the United States has an abundance of water resources. On the average, approximately 4200 billion gallons per day (bgd) are precipitated over the conterminous United States. Of the total supply, only part can be developed for intensive beneficial uses. It is estimated that $1450 \mathrm{bgd}$ are available for such uses. (14) At the present time, the reliable supply with existing surface storage facilities under conditions of low flow, i.e., available supply in 95 out of 100 years, is estimated to be 675 bgd. (14)

During 1975, a total of 393 bgd was withdrawn from surface and ground sources in the conterminous United States. Of this total, 254 bgd were withdrawn from fresh surface-water sources, 58 bgd from saline surface sources, and $81 \mathrm{bdg}$ from sources of groundwater. Of the total water withdrawn, only twenty-five percent was consumed. Therefore, using these data in an aggregated form, it could be concluded that the conterminous United States has a more than adequate supply of fresh water resources to accommodate its needs.

However, fresh water supply and demand are not uniformly distributed across the United States. As a result, local water shortages are common and can to a less extent be present on a regional scale. Although water shortages are generally associated with the arid west, localities in the midwest, northeast, and south have experienced problems of water supply and it is anticipated that the problems will increase in the future.

The Water Resources Planning Act of 1965 (Public Law 89-80) directs the U.S. Water Resources Council to maintain a continuing study of the nation's water and related 1 and resources. In 1968, the Water Resources Council reported the results of its first assessment. (15) The second national assessment was issued in 1978. (14) 
In the second National Water Assessment, the nation was subdivided into 21 major water resource reions and 106 subregions. Eighteen of the regions and 99 of the subregions or aggregated subareas (ASA) are located in the contiguous United States. The eighteen major water resource regions are hydrologic areas that represent the drainage areas for major river systems such as the Columbia, Missouri, etc., or the combined drainage area for a series of similar rivers, i.e., North Atlantic, South Atlantic, etc.

Figure 4.1 shows the 99 contiguous ASA's. During the water policy message to Congress in 1978, the President stated that 21 of the nation's 106 hydrologic basins (i.e. 99 contiguous ASA's plus 7 non-contiguous ASA's) "already have water shortage," and that the number of water-short regions could increase by 18 in the year 2000. (16)

\subsection{COMPETING DEMANDS FOR WATER}

In many respects, the consumptive use of water is more critical than the total quantity of water withdrawn for use. Consumed water is not available for subsequent downstream usage or for groundwater recharge. In a recent study performed for the Water Resources Counci1, (14) the consumptive demand by functional end use was examined.

Consumptive use resulting from offstream use includes agriculture, domestic potable water supply, commercial, manufacturing, mineral production, steam electric power generation, public land and wildlife, and a small "other use" category. Both the supply and demand for water range through the year. Data on the temporal variation in supply and demand for 1975 and a forecast of future supply and demand requirements was recently prepared by the Water Resources Council. (17) A summary of the average annual surface supply and average annual consumptive demand for 1975 and forecasted for the year 2000 is provided in Table 4.1 . 


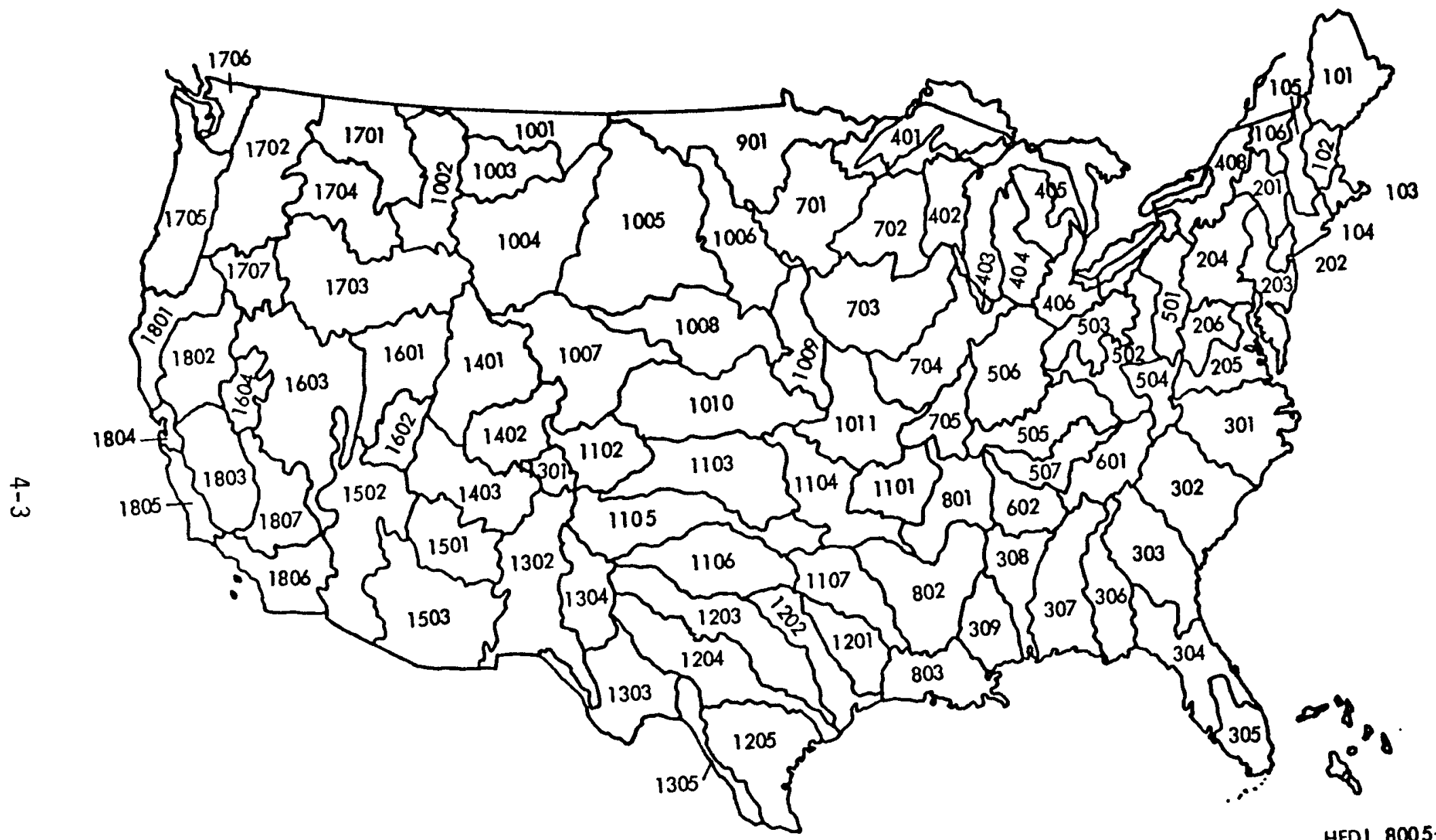

HEDL 8005-108.4

FIGURE 4.1. Location of Aggregated Subareas (ASA) in the Contiguous United States. 
TABLE 4.1

SUMMARY OF AVERAGE ANNUAL FRESH WATER SURFACE SUPPLY AND CONSUMPTIVE DEMAND (Mgd)

\begin{tabular}{|c|c|c|c|}
\hline ASA & $\begin{array}{c}\text { Average Annual } \\
\text { Supply } \\
\end{array}$ & $\begin{array}{r}\text { Ave } \\
\text { Consu } \\
\end{array}$ & \\
\hline & & $19 / 5$ & \\
\hline 0101 & 37900 & 88 & 262 \\
\hline 0102 & 9890 & 35 & 52 \\
\hline 0103 & 4590 & 136 & 256 \\
\hline 0104 & 4780 & 78 & 145 \\
\hline 0105 & 12400 & 120 & 314 \\
\hline 0106 & 8620 & 24 & 34 \\
\hline 0201 & 12200 & 131 & 275 \\
\hline 0202 & 15600 & 493 & 722 \\
\hline 0203 & 15700 & 594 & 989 \\
\hline 0204 & 24500 & 260 & 537 \\
\hline 0205 & 14600 & 232 & 660 \\
\hline 0206 & 8790 & 133 & 365 \\
\hline 0301 & 25900 & 324 & 968 \\
\hline 0302 & 28000 & 292 & 1176 \\
\hline 0303 & 25500 & 184 & 751 \\
\hline 0304 & 18600 & 1132 & 1805 \\
\hline 0305 & 7310 & 2198 & 3112 \\
\hline 0306 & 21800 & 228 & 647 \\
\hline 0307 & 40100 & 172 & 883 \\
\hline 0308 & 41800 & 200 & 442 \\
\hline 0309 & 19000 & 137 & 269 \\
\hline 0401 & 9760 & 132 & 249 \\
\hline 0402 & 9500 & 155 & 352 \\
\hline 0403 & 1230 & 554 & 1121 \\
\hline 0404 & 14700 & 234 & 496 \\
\hline 0405 & 7240 & 80 & 239 \\
\hline 0406 & 7240 & 650 & 1106 \\
\hline
\end{tabular}


TABLE 4.1 (Cont'd)

\begin{tabular}{|c|c|c|c|}
\hline ASA & $\begin{array}{l}\text { Average Annual } \\
\text { Supply } \\
\end{array}$ & \multicolumn{2}{|c|}{$\begin{array}{c}\text { Average Annual } \\
\text { Consumptive Demand } \\
\end{array}$} \\
\hline & & & \\
\hline 0407 & 5040 & 674 & 763 \\
\hline 0408 & 18000 & 119 & 367 \\
\hline 0501 & 19700 & 180 & 290 \\
\hline 0502 & 63700 & 665 & 1553 \\
\hline 0503 & 12500 & 262 & 587 \\
\hline 0504 & 10700 & 111 & 326 \\
\hline 0505 & 178000 & 250 & 702 \\
\hline 0506 & 19700 & 265 & 606 \\
\hline 0507 & 21600 & 65 & 268 \\
\hline 0601 & 23100 & 216 & 628 \\
\hline 0602 & 40800 & 97 & 477 \\
\hline 0701 & 10300 & 206 & 374 \\
\hline 0702 & 26900 & 179 & 356 \\
\hline 0703 & 43300 & 289 & 804 \\
\hline 0704 & 63000 & 254 & 782 \\
\hline 0705 & 121000 & 217 & 372 \\
\hline 0801 & 345000 & 1427 & 1848 \\
\hline 0802 & 387000 & 762 & 1217 \\
\hline 0803 & 433000 & 1838 & 2446 \\
\hline 0901 & 6010 & 112 & 446 \\
\hline 1001 & 5910 & 318 & 545 \\
\hline 1002 & 4770 & 1315 & 2373 \\
\hline 1003 & 5530 & 150 & 262 \\
\hline 1004 & 7760 & 2086 & 4081 \\
\hline 1005 & 14200 & 512 & 757 \\
\hline 1006 & 16500 & 180 & 644 \\
\hline 1007 & 1020 & 3314 & 3553 \\
\hline 1008 & 3920 & 3346 & 4036 \\
\hline 1009 & 24800 & 186 & 294 \\
\hline
\end{tabular}


TABLE 4.1 (Cont'd)

\begin{tabular}{|c|c|c|c|}
\hline ASA & $\begin{array}{c}\text { Average Annual } \\
\text { Supply } \\
\end{array}$ & & \\
\hline & & $\underline{1975}$ & 2000 \\
\hline 1010 & 3910 & 3866 & 3938 \\
\hline 1011 & 44100 & 196 & 430 \\
\hline 1101 & 15900 & 96 & 137 \\
\hline 1102 & 155 & 743 & 635 \\
\hline 1103 & 4280 & 2031 & 2549 \\
\hline 1104 & 27000 & 299 & 619 \\
\hline 1105 & 3540 & 2440 & 2406 \\
\hline 1106 & 2320 & 2276 & 2264 \\
\hline 1107 & 19700 & 179 & 277 \\
\hline 1201 & 10300 & 502 & 1024 \\
\hline 1202 & 7500 & 1601 & 3698 \\
\hline 1203 & 4720 & 4850 & 3073 \\
\hline 1204 & 1810 & 3061 & 2487 \\
\hline 1205 & 3940 & 1245 & 1247 \\
\hline 1301 & 267 & 581 & 685 \\
\hline 1302 & 343 & 1247 & 1321 \\
\hline 1303 & 582 & 630 & 418 \\
\hline 1304 & 122 & 562 & 433 \\
\hline 1305 & 1230 & 1220 & 1159 \\
\hline 1401 & 3680 & 1019 & 1816 \\
\hline 1402 & 4740 & 987 & 1082 \\
\hline 1403 & 10000 & 434 & 934 \\
\hline 1501 & 272 & 73 & 137 \\
\hline 1502 & 1550 & 1059 & 1128 \\
\hline 1503 & 20 & 3463 & 3443 \\
\hline 1601 & 1640 & 1255 & 1251 \\
\hline 1602 & 114 & 599 & 552 \\
\hline 1603 & 132 & 1077 & 1326 \\
\hline 1604 & 676 & 848 & 907 \\
\hline
\end{tabular}


TABLE 4.1 (Cont'd)

Average Annual

ASA Supply

1701

31400

115000

10600

29700

212000

42200

1070

26000

13900

2830

2570

1490

446

139

Average Annual

Consumptive Demand

1975

$\underline{2000}$

626

958

4023

5102

5128

5729

439

741

756

1231

194

489

747

964

737

1015

5398

6204

12649

14657

809

1117

1805

1806

1807

833

1082

5887

5285

328

339 


\subsection{IDENTIFICATION AND DISCUSSION OF WATER RESOURCE CONDITIONS IN POTENTIALLY WATER-SHORT ASAS}

As indicated by the data provided in Table 4.1, the average consumptive demand for water exceeds the average supply of surface water in 15 ASAs. A11 of the ASAs are located in the arid west, preponderantly in the southwestern section of the country. In 17 other ASAs, the average consumptive demand for water exceeds $50 \%$ of the average surface supply. A brief discussion of the specific water resource supply and demand characteristics with in each of these ASAs follows.

ASA 403 - Western Lake Michigan

This area includes the Chicago - Milwaukee metropolitan area. The population of ASA 403 is forecasted to be 3.6 million in the year 2000 . The population is forecasted to be 3.9 million in the year 2020 .

The two major surface water resources in the area are Lake Michigan and the Chicago ship canal, the latter formed by diverting water from Lake Michigan. Water flows from Lake Michigan into the Illinois water-way and eventually into the Mississippi River. Surface water resources are limited.

The Lake Michigan basin has the greatest groundwater potential of any great lakes basin. Glacial drift contains high producing aquifers. However, the sandstone aquifer in the Chicago-Milwaukee area is being "mined" by overpumping in northeast Illinois. Chicago area water levels continue to decline even with excessive use of Lake Michigan water. In 1966 it was estimated that Chicago area pumpage from the principal aquifer, the Cambrian-Ordovician, exceeded its practical substantial yield of $46 \mathrm{Mgd}$ by about 37 Mgd. (18)

The major consumptive use of water in the area is by industry, which, in 1975, was estimated to have been $375 \mathrm{Mgd}$ (578 cfs) and is forecasted to be 
$680 \mathrm{Mgd}(1,050 \mathrm{cfs})$ in the year 2000. The second largest consumptive use of water in ASA 403 is for the purpose of cooling steam electric power plants. (14)

ASA 1002 - Missouri and Marias River Basins

The aggregated subarea includes Helena and Great Falls, Montana. The population of the subarea is projected to increase from approximately 200,000 in the year 1970 to 255,000 in the year 2000 . The population is forecasted to decrease to 246,000 by the year 2020 .

The principal surface water resource of the subarea is the Missouri River. The mean annual flow of the Missouri River at Virgelle, Montana is $8400 \mathrm{cfs}$. Agriculture is the largest single consumer of water resources in the subarea. Institutional constraints, i.e., downstream usage, wildlife preservation, etc. restricts usage of water in the headwaters of the Missouri River Basin. It is assumed that any steam electric power development planned for this subarea will encounter both environmental and political resistance.

In western and central Montana the groundwater resources are largely concentrated in gravel alluvium. Typically these aquifers are high-yield, lowvolume sources of water. The Madison Formation, consolidated sandstone, is located in the vicinity of Great Falls, Montana. The groundwater resources of Eastern Montana are extremely limited. Generally speaking saline groundwater can be found within a depth of 500 feet.

ASA 1004 - Upper Yellowstone, Bighorn, and Powder River Basins

The subarea includes southwestern Montana and the northern portion of Wyoming. The population of the subarea is forecasted to grow from 230,000 (1970) to 355,000 by the year 2000 . Development of coal reserves in this region could accelerate the growth in its population. 
Major surface water resources include the Yellowstone River, Bighorn River, Tongue River and Powder River. The largest single consumption of water in the subarea is irrigation usage for agricultural purposes. Considerable coal exists in this subarea. The Bighorn River Basin and Powder River Basins contain large quantities of subbituminous coal. The development of the coal reserves will require increased consumptive use of the water resources in the region. It is assumed that the availability of water for purposes of cooling steam electric power plants will be limited as a result of water resource requirements imposed by the development of other forms of energy resources into liquid fuels, vis-a-vis synthetic fuel or synfuel development and possible institutional constraints.

The groundwater resources in northern wyoming are scarce and those that exist are not well characterized. Generally speaking, saline groundwater is within 500 feet of the ground surface. Shallow groundwater resources are best located in the alluvium and terrace deposits adjacent to rivers. Deep aquifers, of which the Madison geologic formation is the best known, lie at depths that range from the surface to 8000 feet below the surface. The total dissolved solids (TDS) of water samples taken from the Madison Formation range from 500 to $300,000 \mathrm{mg} / 1$. (19)

\section{ASA 1007 - North and South Platte River Basins}

This area includes Denver, Colorado. The population of the subarea is forcasted to grow from the estimated 1.6 million in 1970 to over 3.0 million in the year 2000, and to increase to $3.5 \mathrm{million}$ by the year 2020 . The subarea is one of the subregions identified as having an inadequate water supply in the SRC's Second National Water Assessment. (14)

The major surface water resources of the subregion include the North Platte and South Platte Rivers. The South Platte River is located northwest of Denver. Irrigation is extensive and is the major consumer of water resources in the region. A critical overdraft of groundwater resources presently exists around Denver. Water resources will be in short supply for al1 new 
uses of water in the subarea. Colorado is an appropriative water rights state, which could further restrict new uses.

There are large quantities of groundwater in sand and gravel deposits along the South Platte and its tributaries downstream of Denver. These (Quaternary) deposits are very highly developed for irrigation and municipal needs. In the valley of the South Platte River, a high rate of recharge due to application of surface water for irrigation so nearly balances current withdrawals plus natural discharge that the quantity of water in storage has remained relatively constant. Long term water level declines in excess of 10 feet have been recorded in tributary valleys east of Denver. Total storage of South Platte alluvial deposits in northeastern Colorado is estimated to be 25,000,000 acre-feet. Approximately $60 \%$ of the wells yield between 300 and 1,000 gallons per minute (gpm). Most aquifers yield less than $200 \mathrm{gpm}$ to wells.

ASA 1008 - Nebraska and North Platte River Basins

This subregion encompasses the state of Nebraska. The region is dominated by agricultural interests. The current population is approximately 670,000 and is forecasted to increase to 770,000 by the year 2000. Agriculture is forecasted to remain the primary use of water resources.

The primary surface water resources are the Nebraska River in the North, and the North Platte River in the South. The flow of the North Platte River is extensively regulated. The average annual consumptive demand is forecasted to exceed the average annual surface supply by 1985.

Groundwater is used extensively in this region of the country. Approximately two-thirds of the peak demand during the summer months of the year is supplied by groundwater. In the eastern part of the state, groundwater is available in glacial deposits and valley sediments. In the western part of the state, the primary source of groundwater is the Ogallala Formation. 
Groundwater in Nebraska is mostly of good quality. Large withdrawals have lowered the water table in many areas of Nebraska. Although the state still has large amounts of good quality groundwater, emphasis on water resource management is extensive and practices of water logging and recharging are common.

ASA 1010 - Kansas River

Geographically this subarea overlaps the northern half of Kansas and the southern edge of Nebraska. The primary economic activity in the subarea is agriculture.

The primary surface water resources of the region are the Republican River and the Kansas River. Several major impoundments, i.e., Harlan Reservoir and Milford Lake, are located along the Republican River. Approximately one third of the peak and agricultural demand during the summer months is provided by surface water resources.

The groundwater resources of Kansas have been extensively developed. In eastern Kansas, groundwater is obtained from alluvial deposits associated with major river flood plains. The major aquifers in the west occur in unconsolidated sands and gravels.

Future aquifer development in Kansas will be hindered by the slow rate of natural recharge. Most of the groundwater supply is located in the arid western part of the state. A gradual water-level decline has existed for many years.

\section{ASA 1102 - Upper Arkansas}

The subarea overlays southeastern Colorado and includes Colorado Springs and Pueb10, Colorado. The population of the subarea is forecasted to grow from 470,000 (1970) to 840,000 in the year 2000 and to be in excess of one million 
by the year 2020. The major surface water resource of the region is the Arkansas River. The mean annual flow rate of the river below John Martin Dam is 240 cfs.

In the western part of the subarea (Central Colorado) the groundwater resources are extremely limited. Most of the aquifers are in beds of sandstone and typically yield only a few gallons or tens of gallons per minute. In the eastern part of the subarea, the primary source of groundwater is the ogallala formation. Generally speaking, the groundwater resources of the subarea have been overdeveloped and overdrafts are extremely common.

The primary use for water in the subarea is for the purpose of irrigation. The maximum agricultural consumptive demand in 1975 was over 3600 Mgd occurring in the month of July. The consumptive demand is forecasted to increase over the next forty years. (14)

At the present time, the water resources of the subarea are inadequate to support the current water use. Water is presently diverted from the Upper Colorado (ASA 1402) into the subarea. Proposed new uses of water will be 1 imited to high priority development.

ASA 1103 - Arkansas and Cimmaron River Regions

The subarea includes southwestern Kansas and northern 0k lahoma. The subarea includes Wichita, Kansas and the influence of Oklahoma City, Oklahoma in the southern region. The population of the subarea is estimated to be approximately 1.34 million and is forecasted to remain relatively constant over the next forty years.

The primary surface water resources in the subarea are the Arkansas River and the Cimmaron River. The mean annual discharge of the Arkansas River at Wichita, Kansas is $2150 \mathrm{cfs}$. The mean annual flow of the Cimmaron River at Mannford, Oklahoma is $1750 \mathrm{cfs}$. 
The primary use of water in the subarea is for agriculture. The consumptive use by agriculture is presently estimated to be 10,000 Mgd and is forecasted to be approximately 15,000 Mgd in the year 2000 .

The usage of groundwater in the subarea is extensive. As implied previously, the Ogallala Formation is the principal source of groundwater in the Great Plains Region of the United States. The Ogallala Formation underlies nearly all of the subarea, but over the years, it has been overdeveloped. Overdrafts are common and the water table has been declining at an average rate of 1.5 to 5.0 feet per year over the last 30 to 40 years.

\section{ASA 1105 - Canadian River}

This subregion extends from northeastern New Mexico, across the Ok lahoma panhandle, and through central Oklahoma and includes Oklahoma City. The population in 1970 was estimated to be 500,000. The population is forecasted to grow to approximately 630,000 by the year 2000. Most of the growth is anticipated to occur in the eastern section of the subarea in the vicinity of Oklahoma City.

The primary surface water resource in the subarea is the Canadian River. The mean annual flow rate of the Canadian River downstream of Eufaula Dam is $4750 \mathrm{cfs}$. The surface water resource in the western half of the subarea is very limited. In the western portion of the subarea, groundwater has been extensively overdeveloped. The most serious water-level declines in the ogallala formation are occurring in the western portion of the subarea.

The primary use for water is agriculture. The consumptive demand resulting from agricultural needs is estimated to be $7500 \mathrm{Mgd}$ and occurs in the month of August. The consumptive demand resulting from agricultural usage is forecasted to remain relatively constant over the next forty years. As suggested previously, most development is forecasted to occur in the eastern half of the subarea. 
ASA 1106 - Red River

The subarea includes the southwest corner of $0 k 1$ ahoma and a strip of Texas along the border between Texas and $0 \mathrm{klahoma.} \mathrm{The} \mathrm{population} \mathrm{of} \mathrm{the} \mathrm{subarea}$ is forecasted to grow from 750,000 (1970) to 1.4 million in the year 2020 .

The primary surface water resources in the subarea are the Red River and the Wichita River. The mean annual flow of the Wichita River at Wichita Falls, Texas is $330 \mathrm{cfs}$. The mean annual flow of the Red River at Denison, Texas is $2,950 \mathrm{cfs}$.

The groundwater resources of the subarea are limited to the alluvial deposits in the vicinity of surface water resources.

The major aquifer in the high plains is the Ogallala Formation. In the western section of the subarea, the water level of most groundwater supplies is declining. In some sections of the region mining of groundwater is common. Groundwater supplies approximately two-thirds of the fresh water supply in the ASA. In the eastern section of the subarea, pumping of groundwater resources has resulted in salt water intrusion. Further development of groundwater resources in subarea 1106 is extremely 1 imited.

Agricultural irrigation is the primary use of water in the subarea. The consumptive use of water for purposes of irrigation was 6,000 Mgd in the year 1975. The agricultural demand is forecasted to increase until the mid-1980's at which time the trend is forecasted to reverse and gradually decrease through the balance of the century.

ASA 1202 - Trinity River

The Trinity River subarea extends from the Texas-0k lahoma border to the Gulf of Mexico. The subarea includes the Dallas Fort Worth complex in the north and Houston in the south. The population of the subarea in 1970 was estimated to be 4.9 million. The population of the subarea is forecasted to grow to 7.6 million in the year 2000 . 
The primary surface water resource in the subarea is the Trinity River. The mean annual discharge of the Trinity River at Dallas, Texas is $640 \mathrm{cfs}$. The mean annual discharge at Romayer, Texas northwest of Houston is $6300 \mathrm{cfs}$.

The primary groundwater resources in the northern portion of the subarea are the Hickory Water Sand, the Ellenburger Formation, and the Trinity group i.e., Travis Peak, and Trinity sand. The formations are intensively developed in the Dallas - Forth Worth area. In the southern portion of the subarea, tertiary sand deposits along the Gulf Coast provide adequate groundwater to a depth of approximately 500 feet. In general, groundwater becomes more saline with depth, and along the coastal zone, the potential degradation resulting from salt water intrusion is a constant threat.

At the present time, the primary consumptive demand for water is agricultural irrigation. In the year 2000, the primary consumptive demand is forecasted to continue to be irrigation; however, the combined effects of other forms of consumptive demand will essentially equal the irrigational demand. The total consumptive demand for water in the year 2000 is forecasted to be $5,300 \mathrm{Mgd}$ or $8180 \mathrm{cfs}$.

\section{ASA 1203 - Brazos River}

The Brazos River Basin extends from eastern New Mexico in the southeasterly direction diagonally across the state of Texas to the Gulf of Mexico. The population of the subarea was $1.3 \mathrm{million}$ in 1970 and is forecasted to increase to 2.0 million by the year 2020 .

Flow of the Brazos River in the upper two-thirds of the basin is low. In the upper or northwestern section of the subarea, the primary source of water is groundwater. In the lower reaches of the Brazos River Basin, the discharge increases. The mean annual flow rate of the Brazos River at Juliff, Texas is $4200 \mathrm{cfs}$. 
The major source of water in the subarea is groundwater and is derived from the Ogallala formation. This formation consists of interconnected sand and gravel mixed with clay, silt and caliche. The saturated thickness of the Ogallala formation ranges up to more than 250 feet. Yields vary from $100 \mathrm{gpm}$ to $1000 \mathrm{gpm}$, with an average of $500 \mathrm{gpm}$. Over the years the Ogallala formation has been seriously overdeveloped. The most serious declines in the formation are presently occurring in the high plains of Texas and New Mexico.

The primary use of water in the subarea is for the purpose of irrigation. At the present time the consumptive demand for irrigation usage is estimated to be approximately $26,000 \mathrm{Mgd}$. This demand is forecasted to decrease to 14,000 Mgd by the year 2000. The electrical energy demand is centered primarily in the central and southern section of the subarea.

ASA 1204 - Colorado River (Texas)

This subarea is located in West Texas. The subarea extends from the State of New Mexico on the west and runs diagonally across the state of Texas to the Gulf of Mexico. It contains the metropolitan area of Austin, Texas. The population of the subarea is forecasted to increase from the present 1.0 million to 1.37 million by the year 2000 .

The primary surface water resource in the subarea is the Colorado River. Flow of the Colorado River in the upper section of the bas in is low and the general water supply is derived from groundwater. The flow rate of the river increases in the lower sections of the basin. The flow of the Colorado River is regulated extensively. The annual average flow at Bay City, Texas is 2100 cfs.

During the summer months groundwater supplies approximately $80 \%$ of the fresh water used in the subarea. The Ogallala Formation is the principal aquifer in the High Plain region of the subarea. Along the coastal region, two major aquifers, the Miocene Coastal sandstones and the Eocene standstones 
supply water. The water of the coastal sandstones is of rather poor quality. The overdraft of groundwater resources is extensive. It is estimated that less than ten percent of the usage rate during the peak summer months is recharged annually. (20)

The primary usage of water is for agriculture. Agricultural usage is forecasted to increase over the next twenty years.

\section{ASA 1301 - Upper Rio Grande}

This subarea is located in south central Colorado and is the headwaters for the Rio Grande River. The area is sparsely populated. The 1970 population was estimated to be 36,000 and the year 2020 population is forecasted to be less than 77,000. In the Rio Grande River basin, water has historically been in short supply as evidenced by the fact that the waters of the Rio Grande River were adjudicated in the early 1890's.

The primary surface water resource in the subarea is the Rio Grande River. The flow rate of this river near the Colorado New Mexico border averages 250 cfs.

Groundwater is primarily located in unconfined valley fill. The valley fill in the Rio Grande Depression which underlies about 5000 square mile comprises the principal groundwater reservoirs in the North Rio Grande subregion.

It is generally believed that most of the economically recoverable fresh groundwater in the Rio Grande River Basin has been developed. New Mexico has large quantities of brackish water in the underground storage. The development of energy resources will probably require the use of saline water. 
The subarea extends from the New Mexico - Colorado border in the north to the Mexican border and cuts a swath through central New Mexico. The subarea includes the metropolitan areas of Albuquerque, New Mexico and El Paso, Texas. The population of the subarea is forecasted to increase from 650,000 in 1970 to $1.4 \mathrm{million}$ in the year 2020 .

The mean annual flow rate of the Rio Grande River at Albuquerque, New Mexico is $930 \mathrm{cfs}$. At Elephant Butte Reservoir north of El Paso, Texas the mean annual flow rate is $750 \mathrm{cfs}$. The surface water of the Rio Grande River Basin was adjudicated in the early 1890's.

In addition to the Rio Grande Depression which is the principal groundwater reservoir in the North Rio Grande subregion, the principal source of groundwater in the vicinity of El Paso is the Rio Grande Mimbres. A bedrock high in the vicinity of Elephant Butte Reservoir tends to separate the groundwater reservoirs in the North Rio Grande subarea from those in the south Rio Grande subregion. The amount of groundwater withdrawn from the $R$ io Grande Mimbres formation in 1970 exceeded the recharge and consequently the water level was declining. The metropolitan area of Albuquerque, New Mexico depends almost entirely upon groundwater as a source of water for public supplies. The groundwater table in the vicinity of Albuquerque has shown a constant decline over the years.

The primary use for water in the subarea is for irrigation. Implementation of new uses of water will require existing uses to be retired. For example, development of the Valles Caldera Geothermal Resources has required the retirement of 35 acres of irrigated farmland to support the development of 150 MW of installed capacity. 
These subareas are located in western Texas and eastern New Mexico. In the upper Pecos River Bas in the present population density is less than 5 individuals per square mile. In the lower reaches of the basin, the 1970 population was estimated to be approximately 375,000 . The population in both regions is forecasted to double by the year 2020 .

The only surface water resource of any consequence in the upper basin is the Pecos River. The flow of that river is merely a few cubic feet per second and the quality of the water is poor. The mean annual flow rate of the Pecos River at Girvin, Texas is $28 \mathrm{cfs}$. In the lower basin, a similar condition exists where the flow rate of the Rio Grande River is essentially depleted in the subarea.

Groundwater has been extensively "mined" in several areas, especially near Roswell and Carlsbad, New Mexico, and in Pecos and Reeves Counties, Texas. The rate of "mining" in the Roswell bas in is estimated to be 120,000 acre-ft annually. Water levels have declined as much as 225 feet in the Artesian aquifer in the Roswe 11 basin and more than 300 feet in Reeves and Pecos Counties, Texas, since groundwater development began.

Fresh water resources, both surface and groundwater, will continue to be in short supply in the Pecos River Basin. Agriculture is the primary use of water. Groundwater is the primary supplier of fresh water. The overdraft in groundwater usage ranges from 25 to $50 \%$ throughout the year. (20)

ASA 1305 - Lower Rio Grande

This subarea is a narrow strip of land in West Texas along the Mexico border. The subarea includes Brownsville, Texas. The population of the subarea is forecasted to increase from the 1970 total of approximately 150,000 to 193,000 in the year 2020 . 
The only significant source of water for cooling in this region is low quality or brackish groundwater and low quality surface water. The primary surface water resource is the Rio Grande River. The average annual flow of the Rio Grande at Brownsville, Texas is $700 \mathrm{cfs}$. However, at times there is no flow in the river. The primary consumptive use of water in the subarea is for irrigation. The present irrigation usage is $3700 \mathrm{Mgd}$ and is forecasted to remain relatively constant over the next twenty years.

The groundwater resources of the Lower Rio Grande River Basin are not extensive. The resources are contained primarily in alluvial deposits in the vicinity of the Rio Grande River. The Oakville sandstone formation and the Goliad water sand formation are two of the rather more significant groundwater deposits in southern Texas. The range in total dissolved solids (TDS) for both formations is 800 to $2000 \mathrm{ppm}$. Well yields in excess of $500 \mathrm{gpm}$ have been obtained.

Agriculture is the primary user of fresh water resources in the subarea. On the average, groundwater supplies less than $10 \%$ of the usage. The average overdraft in the subarea is less than $30 \%$. $(20)$

\section{ASA 1401 - Green River}

This region is located in southwest Wyoming, northwest Colorado, and northeast Utah. The population of the subarea is forecasted to grow from the estimated 140,000 in 1970 to 235,000 in the year 2020. Much of the forecasted growth is predicted on the assumption that the extensive coal and oil shale deposits which exist in the subarea will be developed.

The Green River Formation is estimated to contain more than three trillion barrels of oil equivalent as oil shale. The Department of Interior has leased oil shale tracts in Colorado and Utah to encourage private investment. The locations of the oil shale leases are all in the Green River geological formation. The development of the coal resources into synthetic gas and oil is another proposed development in the Green River Basin. 
The primary surface water resources of the subarea include the Green River, the White River, and the Yampa River. The Green River at Green River, Utah has a mean annual flow rate of 5,900 cfs. The primary use of water in the Green River Basin is for the purpose of irrigation. The mean annual discharge of the Yampa River at Maybe11, Colorado is $1560 \mathrm{cfs}$. The mean annual flow rate of the White River of Watson, Utah is $735 \mathrm{cfs}$. The Yampa and White Rivers flow from east to west. In the Yampa and White River Basins, the primary use of water is for the purpose of irrigation.

The groundwater resources of the Green River Basin are part of the Rocky Mountain System. The Rocky Mountain System is divided into three provinces by extension of adjacent plateaus and basins. The Colorado Plateau province is, for the most part, an arid to semi-arid region in which water supplies are scarce and locally saline. Much of the Colorado Plateau is underlain by tertiary sedimentary rocks of the Wasatch, Battle Springs, and Wind River formations. Small to moderate quantities of water may be obtained locally at shallow depths; however, typically samples of water collected from depths of only a few hundred feet in Western wyoming contain several thousand ppm total dissolved solids.

At the present time, the water resources of the subarea appear adequate to support energy development through the year 2000. However, it is anticipated that the continual development of the energy resources in the Green River Basin will be limited by the availability of fresh water resources and that this will occur during the time period 2000 to 2020 .

\section{ASA 1501 - Little Colorado}

This subarea is located in northeastern Arizona. The continental divide forms the eastern boundary for the subarea. The average elevation of the subarea is over 4000 feet and the rainfall is seasonal and averages less than 16 inches. Although most of the subregion is located in the Navajo Indian Reservation, it is assumed that the general growth of population in Arizona will influence the growth and economic development of the subarea. 
The primary surface water resource of the subarea is the Little Colorado River. The Little Colorado River is subject to periodic droughts. Although the mean annual flow of the river is $580 \mathrm{cfs}$, at times there is no flow in the river.

Most groundwater in the region is obtained from fine-ground sandstone and fractured rock. In northeastern Arizona, the major aquifers are located in the Coconino, Navajo, and Dakota Sandstones. Generally speaking, the Coconino sandstones in Navajo County yield from 300 to $1800 \mathrm{gpm}$ but the water is salty in many places. Groundwater quality is fair to good south of the Little Colorado and Zuni Rivers, but poor to the north.

The primary use for water in the ASA is for irrigation. The demand during the summer months exceeds the average supply. The consumptive demand for water is forecasted to increase by two-thirds by the year 2000. (17) At the present time, groundwater supplies approximately $10 \%$ of the consumptive water needs in the ASA. A slight overdraft presently exists.

\section{ASA 1502 - Colorado River}

This subarea is located in western Arizona and contains Lake Mead and Lake Havasu. The population of the subarea was estimated to be 460,000 in 1970 and is forecasted to be approximately 1.5 million in the year 2000 . The subarea contains Las Vegas, Nevada.

The primary surface water resource in the subarea is the Colorado River. Over the years the Colorado River has been extensively developed, the primary development being the Hoover Dam and Lake Mead Project completed in 1935. Major diversions of Colorado River water exist downstream of Hoover Dam. At Imperial Dam, water is diverted from the Colorado River into the All American Canal for use in the Imperial Valley in California. The water quality in the lower Colorado River is a major concern to agriculture. The 
salinity level of the Colorado River averages approximately $850 \mathrm{ppm}$ and any increase is estimated to have a detrimental effect upon the agricultural interests in the area.

The major aquifers are located in the alluvial basins of the subarea. As a general rate the groundwater resources of the subarea have been overdeveloped. Overpumping is common in the vicinity of Las Vegas.

The primary use for water at the present time is for the purpose of agriculture. Depletion resulting from municipal and industrial usage are forecasted to increase substantially in the lower Colorado River Basin over the next forty years.

ASA 1503 - Gila and Salt Rivers

This subarea, which includes Phoenix and Tucson, Arizona has encountered considerable growth in population over the last twenty years and the forecast is for the growth to continue.

The surface water resources in the subarea are virtually nonexistent. The subarea contains the Gila and Salt Rivers. The upper Gila River is essentially terminated at Coolidge Dam, located approximately fifty miles east of Phoenix. The Salt River flows through Phoenix. Stream flow in the Salt River in the Phoenix area is only on an intermittent basis.

Both the surface and groundwater resources in central Arizona have been over-developed. The groundwater table in the vicinity of Phoenix has been declining for years. The Central Arizona Project, whereby water will be diverted from the Colorado River near Lake Havasu and conveyed to Phoenix, is aimed at stabilizing the groundwater tables. The present demand for water in central Arizona is high and the expectations are that the demand will increase in the years to come. At the present time, approximately one hundred percent of the water supply is provided through the use of groundwater resources. The present overdraft exceeds $4 \times 10^{9}$ gallons per day. 
ASA 1601 - Bear River and Great Salt Lake

The subarea is located in northwest Utah and covers the northeast section of the Great Basin. The population of the subregion, which includes Salt Lake City, Utah, is anticipated to grow from the presently estimated 1 million to over 2 million by the year 2020 .

The primary surface water resources of the subarea are the Bear River and the Great Salt Lake. The Bear River is located to the north of Salt Lake City. The mean annual flow of the Bear River at Corinne, Utah is 1090 cfs.

The alluvial aquifers that occur over much of the subarea are the major sources of groundwater. Bedrock aquifers are less extensive and largely undeveloped. In the vicinity of the Great Salt Lake, groundwater locally contains high concentrations of salt. On the average, groundwater supplies approximately one-fourth of the fresh water demand in the subarea. During the peak-use summer months, groundwater supplies approximately three-fourths of the demand. At the present time, the overdraft is approximately $10 \%$.

The primary consumptive use of water in the subarea is for the purpose of irrigation. Irrigation demand in the year 2000 is forecasted to be $3.3 \times 10^{9}$ gallons per day. Another large demand for water is for reservoir and wet lands managements. The flows of the Weber and Jordan Rivers are largely dedicated to this use.

\section{ASA 1602 - Sevier Lake}

The subarea is located directly south of Salt Lake City, Utah. The population of the area is low and through the year 2000 is forecasted to remain below 100,000 . Most of the growth is anticipated to occur in the northern portion of the subarea south of Salt Lake City.

The subarea is characterized by playas and closed drainage basins. The primary surface water resource is the Sevier river and most of the water has been appropriated. 
Primary aquifers are confined to alluvial deposits located in river valleys. On the average, groundwater supplies provide three times the fresh water that surface water supplies. During the peak summer usage period, the overdraft is extensive and on the average two-thirds of the groundwater consumed is represented by overdraft.

The primary consumptive use for water is irrigation. It is assumed that all future water usage for new energy development in this region will require a transfer of existing water usage. For example, to secure water for the Inter-Mountain Power Project, water rights were purchased from existing agricultural users.

ASA 1603 - Humboldt River

The Humboldt subarea occupies most of the state of Nevada. The average population density of the subarea is less than 3 persons per square mile.

The Humboldt River is the only major surface water resource of any consequence in the subarea. The mean annual flow of the Humboldt River below Rye Patch, Nevada (90 miles northeast of Reno), is less than $200 \mathrm{cfs}$.

The major aquifers in Nevada are Tertiary and Pleistocene coarse-sized deposits in the alluvial basins. Yields of wells obtaining water from fractures in consolidated deposits are variable, although generally only a few gallons per minute. Yields from unconsolidated deposits commonly exceed $500 \mathrm{gpm}$ but fine-grained strata in many basins reduce the yield. Water quality varies considerably. (19)

On the average, groundwater supplies three times the quantity of fresh water that surface water supplies. (16) The general overdraft of the region is estimated to be $50 \%$. 
ASA 1604 - Central Lahontan

The Central Lahonton subarea overlays northwestern Nevada and a strip of land in north central California and includes the cities of Reno, Nevada and Lake Tahoe, California. The 1970 population of the subarea was estimated to be 140,000 and is forecasted to be over 300,000 in the year 2000 .

The principal surface water resources are the Walker River, the Carson River, and the Truckee River. The three rivers flow from the Sierra Nevada Mountains in the western part of the subarea eastward into Nevada. The Carson River terminates in the Carson Sink and Lahontan Reservoir. The Truckee River terminates in Pyramid Lake near Reno, Nevada. The Walker River flows into Walker Lake near Carson City, Nevada.

The groundwater resources of the subarea are not well defined. Groundwater supplies less than ten percent of the total fresh water consumptive demand.

The primary uses for fresh water are for purposes of agriculture. The second largest use is for wildlife management and public lands.

ASA 1703 - Upper and Central Snake Rivers

The subarea is located in southern Idaho. The population of the area is forecasted to grow from 700,000 to approximately 1 million by the year 2000. Most growth is projected to occur near Boise, Idaho.

The principal surface water resource of the subarea is the Snake River and its tributaries. The mean annual surface water discharge in the subarea is approximately $10 \times 10^{9}$ gallons per day. The single largest use of fresh water is agriculture and the mean annual demand during 1975 is estimated to have been approximately $5 \times 10^{9}$ gallons per day.

The groundwater resources of the subarea have not been extensively developed. The groundwater resources along the Snake River are good, and, although the quality varies, generally speaking, it is good. 
The subarea forms a closed bas in of approximately 20,000 sq. miles. The present population is less than 1 person per square mile, making it the least densely populated ASA in the contiguous United States. The population is forecasted to be less than 21,000 in the year 2020 .

Surface water resources are scarce. The largest stream in the subarea is the Silvies River. The mean annual flow of that river at Burns, Oregon is 164 cfs.

The subarea is in the Basin and Range physiographic province. The Basin and Range province is an area of block-faulted mountains of volcanic rock and associated alluvial fills. These formations tend to be permeable and often yield groundwater of high quantity and good quality. The general area has undergone only limited investigation and development.

ASA 1803 - Central and San Joaquin Valleys

This region occupies the central part of California. The 1970 population for the subarea is estimated to have been 2.1 million. The population is forecasted to increase to 3.4 million by the year 2020 .

The primary surface water resource of the subarea is the San Joaquin River. The San Joaquin River flows north and merges with the Sacramento River east of San Francisco. The mean annual flow rate of the San Joaquin River at Vernalis is $2950 \mathrm{cfs}$. Major importations of water include flow from the California Aqueduct, the Friant-Vern Canal and the Delta Mondota Canal.

The major source of groundwater in the subarea consists of numerous alluvial basins. The use and withdrawal of groundwater exceeds recharge and water levels continue to decline. In parts of the San Joaquin Valley, the 
extensive development of groundwater resources and irrigation coupled with poor drainage and alkaline soils has led to the accumulation of considerable salt in the soil.

Agriculture is the largest use of fresh water resources in the subarea. On the average, groundwater supplies five times more water than surface water sources.

ASA 1805 - Central Coast

The central coast subarea lies between San Francisco Bay and Los Angeles. The subarea contains rolling hills and valleys and receives considerable rainfall.

The principal surface water resource of the subarea is the Salinas River. The mean annual flow of the Salinas River near Paso Robles, California is $380 \mathrm{cfs}$. The flow rate of the Salinas River is seasonal with periods of no flow during the summer. The mean annual discharge of surface water resources in the subarea is approximately $2100 \mathrm{cfs}$.

Groundwater resources have been extensively developed. Overdrafts along the coast are common and the threat from salt-water encroachment is a major concern. The Pajaro and Salinas Valleys have been affected by intrusion of sea water into the principal aquifers.

ASA 1806 - South Coast and Colorado Desert

The subarea includes Los Angeles and San Diego extending from the Pacific Ocean on the west to the California-Arizona state boundary. The 1970 population of the subarea was estimated to have been 10.2 million and is forecasted to increase to 16.5 million by the year 2020 . In the west the once valuable citrus areas around Los Angeles are being displaced by urban development. In the east the Imperial Valley continues to produce valuable crops. 
The water resources, both surface and ground, have been overdeveloped in the subarea. For years water has been imported to support development. The Mono Lake and Owens Lake region north of Los Angeles was developed over fifty years ago to support development. Water was diverted to Los Angeles via the Los Angeles Aqueduct. Development in the eastern section of the subarea has been supported by the development and diversion of Colorado River water. Colorado River water is supplied to the Imperial Valley via the All-American canal.

Although agriculture remains the largest user of fresh water resources, the future need for additional water will result primarily from domestic and commercial usage. At the present time groundwater supplies $75 \%$ of the demand. The groundwater overdraft averages $25 \%$ of the groundwater supply.

ASA 1807 - South Lahontan

The South Lahontan Basin is a sparsely populated subarea in southeastern California. The region is characterized by a number of playas and closed basins. Over the years, agriculture has placed the greatest in-basin demand upon the available water resources.

The most notable surface water resources which exist in the Mono Lake and Long Valley include the Owens River, Crowley Lake, and Mono Lake. The mean annual natural runoff for the entire subregion is $1.2 \times 10^{6}$ acre- $\mathrm{ft}$. The surface water resources of the region have been extensively developed by muncipalities of San Diego and Los Angeles. Exports to other subregions in California exceed 350,000 acre-ft. Reallocation of Colorado River water resulting from the Central Arizona Project will require an additional export of water from the Mono-Long subregion.

Mono Lake is part of the surface-water development in the South Lahontan subregion operated by the City of Los Angeles. A tunnel with a capacity of 200 cfs carries water from the Mono Lake Basin into the Owens River Basin. 
The Owens River has its headwaters in the Sierra Nevada Mountains. From its headwaters, the river flows east to Lake Crowley and then in a generally southeasterly direction into the Tinemaha Reservoir. The Los Angeles aqueduct receives its water from the Tinemaha Reservoir.

On the average, use of surface water resources in the subarea is limited to 140 million gallons per day. Groundwater usage averages 450 million gallons per day. At the present time the consumptive demand for water averages 340 million gallons per day. The groundwater overdraft is 140 million gallons per day.

\subsection{WATER REQUIRED BY ENERGY}

Generally speaking, over the years, unit water usage requirements for energy production have decreased. For example, in the late 1930's, an average of about one gallon of water was withdrawn per gallon of petroleum product refined. (14) In 1975, about 0.4 gallons of water were withdrawn to produce the same gallon of petroleum product. Similarly, in the late 1930's on the average, 100 gallons of water were withdrawn to generate a kilowatt hour of electricity. During 1975 less than 50 gallons of water were withdrawn to generate a kilowatt hour.

Although unit water usage withdrawal requirements for energy have generally decreased, for some applications, such as steam electric power generation, the unit water usage consumed has increased. The trend towards more cooling of steam electric power plant condensers with wet, evaporative cooling towers has and will continue to increase the unit consumptive water requirements for cooling system electric plants.

\subsubsection{Water Requirements for Cooling Steam Electric Power Plants}

The primary use of water by steam electric generation stations is for cooling. The quantity of cooling water withdrawn and consumed depends upon the type of power plant, the overall plant thermal efficiency, and the type of 
cooling system used. The trend in power plant cooling is towards an increased use of evaporative cooling towers. These towers consume more water than other forms of power plant cooling. Under typical conditions, total plant consumptive water requirements for a 1000-MWe coal-fired plant would equal 10,000 acre-ft per year $\left(3103 \times 10^{3} \mathrm{lb} / \mathrm{hr}\right)$ of water using an evaporative cooling tower. Under similar conditions, a 1000-MWe nuclear plant would consume 15,000 acre-ft per year $\left(4654 \times 10^{3} \mathrm{lb} / \mathrm{hr}\right)$. By comparison, a cooling pond would consume approximately half the amounts listed.

\subsubsection{Water Requirements for Coal Gasification}

Water is an essential input for the gasification process. Water is required for shift conversion, purification, cooling, steam, sulfur removal, etc. The amount of water required depends upon the type of coal used, the gasification process employed and the type of gas produced. (21) To demonstrate this dependence, Table 4.2 and Table 4.3 are provided. These tables give a summary of the process water requirements (water equivalent hydrogen balance) for both a low Btu and a high Btu gasification plant. (21) Water requirements range from approximately $400 \times 10^{3} \mathrm{lb} / \mathrm{hr}$ for a low Btu gas to approximately $1500 \times 10^{3} \mathrm{lb} / \mathrm{hr}$ for a high Btu gas.

Cooling requirements for coal gasification plants will vary with the type of process used. Based upon data provided in Reference $21,750 \times 10^{3} \mathrm{lb} / \mathrm{hr}$ to $1400 \times 10^{3} \mathrm{lb} / \mathrm{hr}$ for a $250 \times 10^{6}$ scf/day gasification plant will be required. Therefore, the total water requirements for a $250 \times 10^{6} \mathrm{scf} /$ day gasification plant are estimated to range from 1150 to $2900 \times 10^{3} \mathrm{lb} / \mathrm{hr}$ or approximately 3700 to 9350 acre-ft/yr.

\subsubsection{Water Requirements for Coal Liquefaction}

The water requirement for producing liquid fuel from coal depends upon the process employed and the coal characteristics. Basically three approaches are presently being pursued: the liquid hydrocarbon synthes is used and 
TABLE 4.2

WATER EQUIVALENT HYDROGEN BALANCE GASIFICATION PLANT PRODUCING $250 \times 10^{6}$ sCf OF $303 \mathrm{Btu} / \mathrm{sCf}$ GAS, BITUMINOUS COAL (21)

$10^{3} \mathrm{lb} / \mathrm{hr}$

$\underline{\mathrm{gal} / 10^{6} \mathrm{Btu}}$

In

Mo isture in coal

Water equiv. $\mathrm{H}_{2}$ in coal

Steam to gasifier

Water to gasifier

Water to purification

Total

79

164

72

42

2

359

3.0

6.2

2.7

1.6

0.1

out

Water with wet slag

Water with wet ash

Condensation from compression

Condensation in cooling

Water vapor in vent gas

Water equiv. $\mathrm{H}_{2}$ in purification

Water equiv. $\mathrm{H}_{2}$ in product gas

Water vapor in product gas

Total

4
54
30
221
82
3
160
5

359
0.2

2.0

1.1

0.8

3.1

0.1

6.1

0.2

13.6 


\section{TABLE 4.3}

WATER EQUT VALENT HYDROGEN BALANCE: HYGAS PLANT PRODUCING $250 \times 10^{6} \mathrm{scf} /$ day OF $969 \mathrm{Btu} / \mathrm{scf}$ GAS, WYOMING SUBBITUMINOUS COAL(21)

In

Mo isture in coal

Water equiv. $\mathrm{H}_{2}$ in coal

Steam to gasifier

21

0.25

427

5.67

1015

12.07

Total

1513

17.99

Out

Condens ate

294

Water equiv. $\mathrm{H}_{2}$ acid gas

Clean methauotion condensate

Water equiv. $\mathrm{H}_{2}$ in product gas

201

951

0.71

2.39

Total

1506

11.31

17.91 
demonstrated in the SASOL process, the hydroliquefaction process used in producing $\mathrm{H}-\mathrm{Coal}$, and the solvent extraction process used to produce donor coal.

The liquid hydrocarbon synthesis starts with a medium-Btu gas that has been "shifted" and purified to produce synthes is gas that is composed principally of carbon monoxide and hydrogen. The gas is reacted in the presence of a catalyst to produce a variety of liquid hydrocarbons. The process water requirements are largely those related to the manufacture of the medium-Btu gas. The cooling water quantities per unit of heating value in the product fuel relate directly to the conversion efficiency. The overall conversion efficiency is expected to be 65 to 75\%. (21) The cooling water requirement is estimated to range from 1000 to $1500 \times 10^{3} \mathrm{lb} / \mathrm{hr}$ for a 50,000 barrel per day SASOL (1iquid hydrocarbon synthesis) plant.

The process for producing fuel oil directly from coal through using the techniques of hydroliquefaction is being pursued by several organizations. Basically coal is first pulverized, then mixed with oil and hydrogen and fed as a multi-phase flow through a reactor containing a catalyst. Upon leaving the reactor, the remaining gas and coal are centrifuged, separated and recycled. The overall water requirements are assumed to be approximately $1500 \times 10^{3} \mathrm{lb} / \mathrm{hr}$ water equivalent for the processing of a plant producing 50,000 barrels/day. (21) The cooling requirements for the plant are estimated to be $1400 \times 10^{6} \mathrm{lb} / \mathrm{hr} .(21)$

The concept of producing a liquid product directly from coal using a solvent extraction process is similar to the process of hydroliquefaction. The "donor solvent" process is being developed primarily by Exxon and proprietary aspects of the process preclude further discussion. Process water requirements and cooling water requirements are assumed to be comparable with those associated with hydroliquefaction i.e., $1500 \times 10^{3} \mathrm{lb} / \mathrm{hr}$ for processing, and $1400 \times 10^{6} \mathrm{lb} / \mathrm{hr}$ for cooling. 


\subsubsection{Water Requirements for 0il Shale Development}

The process of pyrolysis is used to produce liquid fuel from oil shale. The liquid fuel is the main product of oil shale pyrolysis. The pyrolysis or destructive distillation of shale to produce a crude shale oil, water vapor, and non-condensable gases is termed "retorting". The product of the process is too viscous and too high in nitrogen and sulfur to be used as a synthetic crude for refining. The raw shale oil is upgraded by hydrotreating. (21)

The total water requirements are largely a function of the cooling demand, but are less than the water requirements for coal liquefaction and gasification. Process water requirements are assumed to be provided by the moisture contained in the oil shale. Cooling water requirements are assumed to range from 1000 to $1500 \times 10^{3} \mathrm{lb} / \mathrm{hr}$ for a 50,000 barrel/day oil shale plant.

\section{$4.4 \quad$ INSTITUTIONAL CONSTRAINTS}

In terms of water rights and water resource usage, the contiguous United States is basically split in half. In the eastern half of the country the climate tends to be humid and riparian water law governs its use. As such, in the east, almost by definition, water will be available for power plant cooling provided its use does not infringe upon other uses of the resource, i.e., "reasonable usage". In the generally arid Western half of the United States, the climatic conditions support the use of the appropriative rights doctrine. The appropriative rights doctrine is best summarized by ... "first in time is first in right", and is supported by principles of beneficial usage. As such, priority and priority usage become very important considerations when considering future usage. It is assumed that future water requirements for cooling thermal power plants have not at the present time been secured and will be reviewed with respect to the legal climate which presently exists in the Western United States towards establishing a legal claim to the use of water for cooling steam electric power plants. 
In the American West, the initial use of water was for the purpose of working mines and irrigating crops. Both of these uses required that water often be diverted and conveyed, restricting the use of riparian water law. Furthermore, unlike eastern water usage, diversion of water meant a faster depletion of an already scarce resource. Very often not enough water was available to satisfy all demands and conflicts followed. The appropriative doctrine was born in this climate and remains in practice today.

In much of the West water supplies are almost fully developed. New uses will require that water rights be secured from existing uses. As a general rule water may be transferred to a new place of use or purpose of use provided the transfer does not cause injury to existing appropriations. However, in several states, additional restrictions have been imposed which could seriously affect the securing of water rights for purposes of energy development which generally includes the cooling of steam electric power plants.

"...North Dakota, South Dakota, and Arizona have provisions which impede, if not completely preclude, the transfer of irrigation rights to energy use. These provisions are a serious limitation, since irrigation is the most likely source of water to be transferred to energy development. Montana also has provisions which, while not as broadly applicable as those in the preceding states, seriously inhibit the transfer of water to energy use. The Montana and North Dakota provisions are of recent origin and were clearly a reaction to impending energy development. In addition to their impact on the availability of water for energy development, these statutes once again reveal that energy development is not being greeted with unbridled enthusiasm, particularly where it promises to alter existing life-styles drastically...".(22)

Three states, Nevada, Wyoming, and California, authorize the administrator to consider the public interest in determining whether to approve a transfer. Consideration of the public interest introduces an additional impediment which could seriously affect the water rights transfer process. 
Two states, Colorado and Utah, have adopted a "wait and see" attitude where the effect of a transfer of water right is unclear. That is, these states allow the transfer, subject to future readjustment if injury does occur. In no case can a water right be simply bought and sold.

Two states, Idaho and New Mexico, allow for water rights to be transferred in a rather expeditious manner. Typically a permit is first filed. A notice of the proposed appropriation is published and interested persons are given an opportunity to protest. The governing body, i.e., in Idaho the Director of Department of Water Resources, in New Mexico the State Engineer, conducts hearings and, based upon the data presented, renders a decision.

In Nebraska, Kansas, Oklahoma, Texas, Washington, and Oregon a dual doctrine exists. In these areas it is assumed that water will be available for purposes of power plant cooling provided the resource has not been exhausted from other uses.

The water resources of West Texas and West $0 k$ lahoma have been overused. The Ogallala formation which underlies the general region has experienced an extensive overdraft in recent years. A considerable growth in population is anticipated for both Texas and Oklahoma. The agricultural base in both states is anticipated to grow. However, both states tend to be industrial and manufacturing oriented, which should assist the electric utility industry in securing water for power plant cooling.

The States of Washington and Oregon are similar. Both Western Washington and Oregon have an abundance of surface water resources. East of the Cascade Mountain Range, however, surface water is scarce. An exception to this pattern is the basin of the Columbia River, which flows north-to-south through the central part of Washington and then forms the border between Oregon and Washington. The quantity of water resources in the states of Oregon and Washington is sufficient to support most energy development scenarios. Water quality considerations and other environmental concerns present the biggest obstacle in securing water use permits. 


\subsection{AN ASSESSMENT OF REQUIREMENTS FOR DRY COOLING}

\subsection{INSTALLED CAPACITY BY AGGREGATED SUBAREA}

A methodology was developed to disaggregate the installed capacity forecasts described in the previous sections. The methodology which was developed used what might be termed "per capita regional installed capacity factors", aggregated load growth forecast data and forecasted population growth statistics to simulate a picture of future load growth.

As mentioned previously, in the second National Water Assessment, ${ }^{(14)}$ the nation was subdivided into 21 major water resource regions and 106 subregions. Eighteen of the regions and 99 of the subregions are located in the contiguous United States. The eighteen major water resource regions are hydrologic areas that represent the drainage area for major river systems, i.e., Columbia, Missouri, etc., or the combined drainage area for a group of rivers having similar characteristics, i.e., North Atlantic, South Atlantic, etc. Figure 2.1 shows the ninety-nine contiguous ASAs used herein.

Population projections were developed using the MULTIREGION set of computer models developed at Oak Ridge National Laboratory. ${ }^{(23)}$ To produce the specific set of population projections for each state, census Series II and OBERS National Employment values were used as controls. The MULTIREGION model used in the analys is develops projections of population and employment by combining demographic and economic behavior data. Birth and death relationships for the resident population and migratory tendencies are evaluated.

Population forecasts for each state were disaggregated into ASAs using correlation coefficients derived from 1975 Census Data. Overlay techniques were used to apportion state and county population data into appropriate ASAs. Projected annual population growth for each ASA were calculated using the MULTIREGION forecasted state population data base and the explicitly derived scaling factors. Table 5.1 lists the forecasted population for each ASA in the years 2000 and 2020. 
TABLE 5.1

FORECASTED POPULATION FOR EACH ASA

(Thousands)

\begin{tabular}{|c|c|c|}
\hline ASA & 2000 & 2020 \\
\hline 0101 & 882 & 894 \\
\hline 0102 & 2691 & 3064 \\
\hline 0103 & 5574 & 6785 \\
\hline 0104 & 2981 & 3440 \\
\hline 0105 & 2542 & 2993 \\
\hline 0106 & 541 & 569 \\
\hline 0201 & 1960 & 2090 \\
\hline 0202 & 16786 & 18258 \\
\hline 0203 & 8518 & 8819 \\
\hline 0204 & 3914 & 4052 \\
\hline 0205 & 6279 & 7069 \\
\hline 0206 & 4584 & 5265 \\
\hline 0301 & 4546 & 4905 \\
\hline 0302 & 5978 & 6499 \\
\hline 0303 & 3694 & 4260 \\
\hline 0304 & 7392 & 9410 \\
\hline 0305 & 6403 & 8216 \\
\hline 0306 & 3208 & 3753 \\
\hline 0307 & 2900 & 3037 \\
\hline 0308 & 1766 & 1849 \\
\hline 0309 & 1567 & 1681 \\
\hline 0401 & 426 & 469 \\
\hline 0402 & 1337 & 1462 \\
\hline 0403 & 3574 & 3908 \\
\hline 0404 & 3327 & 3647 \\
\hline 0405 & 1767 & 1937 \\
\hline 0406 & 7349 & 7906 \\
\hline 0407 & 4545 & 4742 \\
\hline 0408 & 2585 & 2759 \\
\hline
\end{tabular}


TABLE 5.1 (Cont'd)

\begin{tabular}{|c|c|c|}
\hline ASA & 2000 & 2020 \\
\hline 0501 & 3295 & 3274 \\
\hline 0502 & 5394 & 5593 \\
\hline 0503 & 4450 & 4585 \\
\hline 0504 & 895 & 854 \\
\hline 0505 & 3658 & 3896 \\
\hline 0506 & 4035 & 4260 \\
\hline 0507 & 1722 & 1773 \\
\hline 0601 & 2723 & 2804 \\
\hline 0602 & 1292 & 1346 \\
\hline 0701 & 3483 & 3837 \\
\hline 0702 & 1727 & 1889 \\
\hline 0703 & 4530 & 4708 \\
\hline 0704 & 9433 & 10227 \\
\hline 0705 & 2680 & 2908 \\
\hline 0801 & 2534 & 2709 \\
\hline 0802 & 2166 & 2374 \\
\hline 0803 & 3232 & 2370 \\
\hline 0901 & 813 & 782 \\
\hline 1001 & 87 & 83 \\
\hline 1002 & 255 & 246 \\
\hline 1003 & 40 & 38 \\
\hline 1004 & 355 & 347 \\
\hline 1005 & 498 & 449 \\
\hline 1006 & 573 & 501 \\
\hline 1007 & 2997 & 3526 \\
\hline 1008 & 771 & 803 \\
\hline 1009 & 1425 & 1446 \\
\hline 1010 & 1230 & 1220 \\
\hline 1011 & 2640 & 2816 \\
\hline 1101 & 857 & 967 \\
\hline
\end{tabular}


TABLE 5.1 (Cont'd)

\begin{tabular}{|c|c|c|}
\hline ASA & 2000 & 2020 \\
\hline 1102 & 840 & 1000 \\
\hline 1103 & 1318 & 1341 \\
\hline 1104 & 2356 & 2527 \\
\hline 1105 & 582 & 630 \\
\hline 1106 & 1182 & 1390 \\
\hline 1107 & 1447 & 1722 \\
\hline 1201 & 1055 & 1390 \\
\hline 1202 & 7607 & 9043 \\
\hline 1203 & 2016 & 2400 \\
\hline 1204 & 1366 & 1625 \\
\hline 1205 & 3148 & 3747 \\
\hline 1301 & 64 & 77 \\
\hline 1302 & 1231 & 1412 \\
\hline 1303 & 587 & 699 \\
\hline 1304 & 188 & 217 \\
\hline 1305 & 163 & 193 \\
\hline 1401 & 201 & 235 \\
\hline 1402 & 273 & 325 \\
\hline 1403 & 234 & 271 \\
\hline 1501 & 289 & 404 \\
\hline 1502 & 2348 & 3426 \\
\hline 1503 & 1499 & 2093 \\
\hline 1601 & 1744 & 2112 \\
\hline 1602 & 82 & 102 \\
\hline 1603 & 326 & 408 \\
\hline 1604 & 304 & 382 \\
\hline 1701 & 688 & 655 \\
\hline 1702 & 831 & 893 \\
\hline 1703 & 908 & 959 \\
\hline 1704 & 75 & 3 \\
\hline
\end{tabular}


TABLE 5.1 (Cont'd)

ASA

2000

2020

1705

3193

3457

1706

2529

2690

1707

374

407

1801

640

760

1802

1738

2062

1803

2897

3437

1804

2044

2425

1805

5103

6054

1806

14167

16487

1807

64

76

$5-5$ 
The basic relationship which was used to disaggregate the forecasted electrical capacity load growth is written as follows:

$$
c_{(i, k)}=\left(\frac{C_{(i, j)}}{P_{(i, j)}}\right)\left(\frac{E_{(k)}}{E_{(j)}}\right) \operatorname{Pop}_{(i, k)}
$$

where:

$$
\begin{aligned}
C_{(i, k)} & =\text { installed capacity in ASA } i \text { at time } k \\
P(i, j) & =\text { population in ASA } i \text { at time } j \\
C_{(i, j)} & =\text { installed capacity in ASA } i \text { at time } j \\
E(k) & =\text { installed (forecasted) capacity (national) at time } k \\
E(j) & =\text { installed capacity (national) at time } j \\
\text { Pop }(i, k) & =\text { population (forecasted) in ASA } i \text { and time } k
\end{aligned}
$$

Using relationship 5.1, the installed capacity for each ASA was calculated for the years 2000 and 2020 using the load growth data shown in Table 3.1 and the population data shown in Table 5.1. The conditions which existed in 1980 were used to initialize the analysis. The results of the analysis are provided in Table 5.2 .

\subsection{REPLACEMENT CAPACITY}

In addition to load growth capacity requirements, replacement capacity requirements were analyzed. Assuming a 40-year plant life for a steam electric power plant, the installed capacity represented by thermal power plants constructed during the 1960's and 1970's will be retired during the period 2000 to 2020 .

During the 1960's, approximately 195 GWe of generating capacity was installed. Using the Water Use Information System (WUIS), (24) a listing of the steam electric thermal power plants constructed during the 1960's was prepared and organized with respect to the resident ASA. Approximately 
TABLE 5.2

FORECASTED ELECTRICAL ENERGY LOAD GROWTH REQUIREMENT (GWe)

\begin{tabular}{|c|c|c|c|c|c|c|}
\hline \multirow{2}{*}{$\begin{array}{c}\text { ASA } \\
\text { Scenario } \\
\end{array}$} & \multicolumn{3}{|c|}{ Year 2000 Forecast } & \multicolumn{3}{|c|}{ Year 2020 Forecast } \\
\hline & Low & Medium & High & Low & Medium & High \\
\hline 0101 & 2 & 2 & 2 & 2 & 2 & 3 \\
\hline 0102 & 2 & 2 & 2 & 2 & 2 & 3 \\
\hline 0103 & 9 & 10 & 12 & 10 & 13 & 17 \\
\hline 0104 & 8 & 9 & 11 & 9 & 12 & 16 \\
\hline 0105 & 4 & 5 & 6 & 5 & 6 & 9 \\
\hline 0106 & 0 & 0 & 0 & 0 & 0 & 0 \\
\hline 0201 & 3 & 4 & 5 & 4 & 5 & 8 \\
\hline 0202 & 29 & 32 & 37 & 33 & 39 & 53 \\
\hline 0203 & 18 & 21 & 24 & 22 & 27 & 36 \\
\hline 0204 & 9 & 10 & 11 & 9 & 12 & 16 \\
\hline 0205 & 20 & 22 & 25 & 23 & 28 & 38 \\
\hline 0206 & 9 & 10 & 13 & 11 & 13 & 19 \\
\hline 0301 & 19 & 21 & 25 & 23 & 28 & 38 \\
\hline 0302 & 27 & 30 & 33 & 29 & 36 & 49 \\
\hline 0303 & 15 & 16 & 20 & 18 & 23 & 31 \\
\hline 0304 & 29 & 34 & 42 & 37 & 45 & 61 \\
\hline 0305 & 26 & 28 & 35 & 31 & 39 & 53 \\
\hline 0306 & 12 & 14 & 18 & 15 & 20 & 27 \\
\hline 0307 & 12 & 13 & 16 & 13 & 16 & 23 \\
\hline 0308 & 7 & 8 & 10 & 8 & 10 & 14 \\
\hline 0309 & 3 & 4 & 6 & 5 & 6 & 9 \\
\hline 0401 & 2 & 2 & 2 & 2 & 2 & 3 \\
\hline 0402 & 5 & 5 & 6 & 5 & 6 & 9 \\
\hline 0403 & 10 & 12 & 16 & 13 & 16 & 23 \\
\hline 0404 & 14 & 16 & 20 & 17 & 22 & 30 \\
\hline 0405 & 8 & 9 & 11 & 9 & 12 & 16 \\
\hline 0406 & 32 & 37 & 43 & 38 & 47 & 55 \\
\hline 0407 & 16 & 19 & 22 & 21 & 25 & 34 \\
\hline
\end{tabular}


TABLE 5.2 (Cont'd)

ASA

Scenario

0408

0501

0502

0503

0504

0505

0506

0507

0601

0602

0701

0702

0703

0704

0705

0801

0802

0803

0901

1001

1002

1003

1004

1005

1006

1007

1008

1009

1010

1011
Year 2000 Forecast

\begin{tabular}{ccc} 
Low & & Med \\
\hline 2 & & \\
13 & & 13 \\
21 & & 21 \\
22 & & 24 \\
4 & & \\
16 & & \\
18 & &
\end{tabular}

7

11

6

11

5

15

32

9

12

6

8

2

0

0

0

1

2

1

9

1

7

7

9
Medium High

3

13

21

24

4

17

20

8

12

6

13

6

17

36

10

14

6

10

3

0

0

0

1

1

2

1

11

2

8

8

9
4

15

22

26

5

21

23

10

15

7

17

8

21

42

12

18

8

12

4

0

1

0

1

2

1

15

3

10

10

12

5-8
Year 2020 Forecast

Medium High

$\frac{\text { Low }}{3} \quad \frac{\text { Medium }}{4} \quad \frac{\text { High }}{5}$

13

16

22

20

25

34

24

29

40

5

8

18

24

32

21

26

35

10

14

16

22

7

9

19

26

9

12

24

31

46

61

13

17

20

27

10

14

12

16

4

5

0

0

1

0

3

3

3

22

4

14

14

11

15 
TABLE 5.2 (Cont'd)

\begin{tabular}{|c|c|c|c|c|c|c|}
\hline \multirow{2}{*}{$\begin{array}{c}\text { ASA } \\
\text { Scenario }\end{array}$} & \multicolumn{3}{|c|}{ Year 2000 Forecast } & \multicolumn{3}{|c|}{ Year 2020 Forecast } \\
\hline & Low & Medium & High & Low & Medium & High \\
\hline 1101 & 5 & 6 & 8 & 7 & 9 & 12 \\
\hline 1102 & 5 & 6 & 8 & 7 & 9 & 12 \\
\hline 1103 & 9 & 9 & 12 & 10 & 13 & 17 \\
\hline 1104 & 14 & 18 & 21 & 18 & 23 & 31 \\
\hline 1105 & 9 & 10 & 13 & 11 & 13 & 19 \\
\hline 1106 & 3 & 3 & 5 & 4 & 5 & 8 \\
\hline 1107 & 5 & 5 & 6 & 5 & 6 & 9 \\
\hline 1201 & 4 & 4 & 5 & 4 & 5 & 8 \\
\hline 1202 & 26 & 30 & 34 & 30 & 36 & 48 \\
\hline 1203 & 8 & 9 & 11 & 9 & 12 & 16 \\
\hline 1204 & 3 & 3 & 4 & 3 & 4 & 5 \\
\hline 1205 & 10 & 11 & 14 & 12 & 15 & 21 \\
\hline 1301 & 0 & 0 & 0 & 0 & 1 & 2 \\
\hline 1302 & 3 & 4 & 5 & 4 & 5 & 8 \\
\hline 1303 & 2 & 2 & 3 & 3 & 3 & 4 \\
\hline 1304 & 0 & 0 & 1 & 1 & 1 & 1 \\
\hline 1305 & 0 & 0 & 1 & 1 & 2 & 3 \\
\hline 1401 & 1 & 1 & 1 & 1 & 1 & 1 \\
\hline 1402 & 1 & 1 & 1 & 1 & 2 & 3 \\
\hline 1403 & 1 & 1 & 1 & 1 & 1 & 1 \\
\hline 1501 & 0 & 0 & 1 & 1 & 2 & 3 \\
\hline 1502 & 4 & 4 & 5 & 4 & 5 & 8 \\
\hline 1503 & 11 & 14 & 17 & 14 & 19 & 26 \\
\hline 1601 & 4 & 5 & 7 & 6 & 7 & 9 \\
\hline 1602 & 0 & 0 & 0 & 0 & 0 & 0 \\
\hline 1603 & 1 & 1 & 1 & 1 & 2 & 3 \\
\hline 1604 & 1 & 1 & 1 & 1 & 2 & 3 \\
\hline 1701 & 3 & 3 & 3 & 3 & 3 & 4 \\
\hline 1702 & 3 & 3 & 3 & 3 & 3 & 4 \\
\hline
\end{tabular}


TABLE 5.2 (Cont'd)

\begin{tabular}{|c|c|c|c|c|c|c|}
\hline \multirow{2}{*}{$\begin{array}{c}\text { ASA } \\
\text { Scenario } \\
\end{array}$} & \multicolumn{3}{|c|}{ Year 2000 Forecast } & \multicolumn{3}{|c|}{ Year 2020 Forecast } \\
\hline & Low & Medium & High & Low & Medium & High \\
\hline 1703 & 3 & 3 & 3 & 3 & 2 & 3 \\
\hline 1704 & 2 & 2 & 2 & 2 & 2 & 3 \\
\hline 1705 & 9 & 10 & 13 & 11 & 13 & 19 \\
\hline 1706 & 9 & 9 & 11 & 9 & 12 & 16 \\
\hline 1707 & 0 & 0 & 0 & 0 & 0 & 0 \\
\hline 1801 & 1 & 2 & 3 & 3 & 3 & 4 \\
\hline 1802 & 5 & 6 & 8 & 7 & 9 & 12 \\
\hline 1803 & 9 & 9 & 12 & 10 & 13 & 17 \\
\hline 1804 & 15 & 17 & 20 & 18 & 23 & 32 \\
\hline 1805 & 5 & 5 & 6 & 5 & 6 & 9 \\
\hline 1806 & 45 & 49 & 58 & 52 & 64 & 86 \\
\hline 1807 & 4 & 4 & 5 & 4 & 5 & 8 \\
\hline
\end{tabular}


$146 \mathrm{GW}$ of the $195 \mathrm{GW}$ installed during the 1960's is classified as steam electric generating capacity and was assumed to be replaced during the time period 2000 to 2010 .

Using the same approach, the capacity installed during the 1970's and assumed to be replaced during the time period 2010 to 2020 was analyzed. It was estimated that during the 1970's, approximately $240 \mathrm{GW}$ of generating capacity was installed. Approximately $216 \mathrm{GW}$ of the $240 \mathrm{GW}$ of capacity installed during the 1970 's was classified as steam electric generating capacity and assumed to be replaced.

The total replacement capacity requirements are forecasted to be $360 \mathrm{GW}$ over the 20-year time period 2000 to 2020. The replacement capacity for each ASA is provided in Table 5.3 .

\subsection{LOAD GROWTH AND REPLACEMENT CAPACITY REQUIREMENTS}

Tables $5.4,5.5$ and 5.6 summarize the construction requirements resulting from the load growth and replacement capacity requirements tabulated in Tables 5.2 and 5.3. Using the scenario described previously, the construction requirements were found to range from 560 to 1160 GWs equivalent of steam electric power generation capability during the time period 2000 to 2020 .

\section{$5.4 \quad$ LOCATION OF SYNFUEL PLANTS}

In a study performed by the Water Resources Council, the potential impact of siting synfuel facilities on the water resources of the Upper Missouri River Basin was investigated. (25) Two hypothetical levels of synfuel development potential, a base case and an accelerated case, were reviewed. As a basis for analysis, an aggregated national consumption of 98 quads in the year 1985 and 143 quads in the year 2000 were assumed. A standard size facility producing synthetic fuel with an energy equivalent of $250 \times 10^{9}$ Btu per day was used. For the base case scenario, a total of 21 such 
TABLE 5.3

REPLACEMENT CAPACITY CONSTRUCTION REQUIREMENT (GWe)

\begin{tabular}{|c|c|c|}
\hline ASA & $2000-2010$ & $2010-2020$ \\
\hline 0101 & 0 & 1 \\
\hline 0102 & 0 & 2 \\
\hline 0103 & 4 & 1 \\
\hline 0104 & 1 & 2 \\
\hline 0105 & 1 & 1 \\
\hline 0106 & 0 & 0 \\
\hline 0201 & 1 & 2 \\
\hline 0202 & 6 & 5 \\
\hline 0203 & 4 & 4 \\
\hline 0204 & 3 & 7 \\
\hline 0205 & 2 & 4 \\
\hline 0206 & 2 & 2 \\
\hline 0301 & 3 & 6 \\
\hline 0302 & 3 & 4 \\
\hline 0303 & 2 & 6 \\
\hline 0304 & 4 & 7 \\
\hline 0305 & 3 & 2 \\
\hline 0306 & 1 & 2 \\
\hline 0307 & 2 & 6 \\
\hline 0308 & 2 & 1 \\
\hline 0309 & 0 & 1 \\
\hline 0401 & 0 & 1 \\
\hline 0402 & 0 & 3 \\
\hline 0403 & 1 & 3 \\
\hline 0404 & 1 & 6 \\
\hline 0405 & 1 & 1 \\
\hline 0406 & 1 & 3 \\
\hline 0407 & 3 & 1 \\
\hline 0408 & 1 & 1 \\
\hline
\end{tabular}


TABLE 5.3 (Cont'd)

\begin{tabular}{|c|c|c|}
\hline ASA & $2000-2010$ & $2010-2020$ \\
\hline 0501 & 7 & 5 \\
\hline 0502 & 6 & 6 \\
\hline 0003 & 0 & 1 \\
\hline 0504 & 0 & 4 \\
\hline 0505 & 5 & 2 \\
\hline 0506 & 2 & 5 \\
\hline 0507 & 1 & 3 \\
\hline 0601 & 3 & 0 \\
\hline 0602 & 1 & 4 \\
\hline 0701 & 1 & 4 \\
\hline 0702 & 1 & 2 \\
\hline 0703 & 2 & 3 \\
\hline 0704 & 5 & 8 \\
\hline 0705 & 2 & 4 \\
\hline 0801 & 1 & 2 \\
\hline 0802 & 2 & 3 \\
\hline 0803 & 4 & 1 \\
\hline 0901 & 0 & 0 \\
\hline 1001 & 0 & 0 \\
\hline 1002 & 0 & 0 \\
\hline 1003 & 0 & 0 \\
\hline 1004 & 1 & 1 \\
\hline 1005 & 2 & 1 \\
\hline 1006 & 0 & 0 \\
\hline 1007 & 1 & 4 \\
\hline 1008 & 0 & 0 \\
\hline 1009 & 1 & 0 \\
\hline 1010 & 0 & 1 \\
\hline 1011 & 1 & 5 \\
\hline 1101 & 1 & 1 \\
\hline
\end{tabular}


TABLE 5.3 (Cont'd)

\begin{tabular}{|c|c|c|}
\hline ASA & $2000-2010$ & $2010-2020$ \\
\hline 1102 & 0 & 0 \\
\hline 1103 & 1 & 1 \\
\hline 1104 & 2 & 4 \\
\hline 1105 & 1 & 3 \\
\hline 1106 & 0 & 1 \\
\hline 1107 & 2 & 3 \\
\hline 1201 & 2 & 2 \\
\hline 1202 & 4 & 6 \\
\hline 1203 & 3 & 6 \\
\hline 1204 & 1 & 3 \\
\hline 1205 & 1 & 3 \\
\hline 1301 & 0 & 0 \\
\hline 1302 & 0 & 0 \\
\hline 1303 & 0 & 0 \\
\hline 1304 & 0 & 0 \\
\hline 1305 & 0 & 0 \\
\hline 1401 & 0 & 4 \\
\hline 1402 & 1 & 2 \\
\hline 1403 & 3 & 3 \\
\hline 1501 & 1 & 0 \\
\hline 1502 & 1 & 3 \\
\hline 1503 & 1 & 2 \\
\hline 1601 & 0 & 0 \\
\hline 1602 & 0 & 0 \\
\hline 1603 & 0 & 0 \\
\hline 1604 & 1 & 0 \\
\hline 1701 & 1 & 1 \\
\hline 1702 & 3 & 1 \\
\hline 1703 & 3 & 1 \\
\hline 1704 & 0 & 1 \\
\hline 1705 & 1 & 3 \\
\hline
\end{tabular}


TABLE 5.3 (Cont'd)

$\begin{array}{ccc}\text { ASA } & \frac{2000-2010}{1706} & \frac{2010-2020}{170} \\ 1707 & 0 & 0 \\ 1801 & 0 & 0 \\ 1802 & 1 & 0 \\ 1803 & 3 & 0 \\ 1804 & 1 & 2 \\ 1805 & 0 & 1 \\ 1806 & 0 & 1 \\ 1807 & 5 & 2 \\ & 0 & 0\end{array}$


TABLE 5.4

CAPACITY ADDITIONS: LOAD GROWTH AND REPLACEMENT

2000 TO 2020 (GW)

LOW GROWTH SCENARIO

\begin{tabular}{|c|c|c|c|}
\hline ASA & Load Growth & Replacement & Total \\
\hline 0101 & 0 & 1 & 1 \\
\hline 0102 & 0 & 2 & 2 \\
\hline 0103 & 1 & 5 & 6 \\
\hline 0104 & 1 & 3 & 4 \\
\hline 0105 & 1 & 2 & 3 \\
\hline 0106 & 0 & 0 & 0 \\
\hline 0201 & 1 & 3 & 4 \\
\hline 0202 & 4 & 11 & 15 \\
\hline 0203 & 4 & 8 & 12 \\
\hline 0204 & 0 & 10 & 10 \\
\hline 0205 & 3 & 6 & 9 \\
\hline 0206 & 2 & 4 & 6 \\
\hline 0301 & 4 & 9 & 13 \\
\hline 0302 & 2 & 7 & 9 \\
\hline 0303 & 3 & 8 & 11 \\
\hline 0304 & 8 & 11 & 19 \\
\hline 0305 & 5 & 5 & 10 \\
\hline 0306 & 3 & 3 & 6 \\
\hline 0307 & 1 & 8 & 9 \\
\hline 0308 & 1 & 3 & 4 \\
\hline 0309 & 2 & 1 & 3 \\
\hline 0401 & 0 & 1 & 1 \\
\hline 0402 & 0 & 3 & 3 \\
\hline 0403 & 3 & 4 & 7 \\
\hline 0404 & 3 & 7 & 10 \\
\hline 0405 & 1 & 2 & 3 \\
\hline 0406 & 6 & 4 & 10 \\
\hline 0407 & 5 & 4 & 9 \\
\hline
\end{tabular}


TABLE 5.4 (Cont'd)

\begin{tabular}{|c|c|c|c|}
\hline ASA & Load Growth & Replacement & Total \\
\hline 0408 & 1 & 2 & 3 \\
\hline 0501 & 0 & 12 & 12 \\
\hline 0502 & -1 & 12 & 11 \\
\hline 0503 & 2 & 1 & 3 \\
\hline 0504 & 0 & 4 & 4 \\
\hline 0505 & 2 & 7 & 9 \\
\hline 0506 & 3 & 7 & 10 \\
\hline 0507 & 1 & 4 & 5 \\
\hline 0601 & 2 & 3 & 5 \\
\hline 0602 & 0 & 5 & 5 \\
\hline 0701 & 3 & 5 & 8 \\
\hline 0702 & 2 & 3 & 5 \\
\hline 0703 & 3 & 5 & 8 \\
\hline 0704 & 5 & 13 & 18 \\
\hline 0705 & 1 & 6 & 7 \\
\hline 0801 & 3 & 3 & 6 \\
\hline 0802 & 1 & 5 & 6 \\
\hline 0803 & 2 & 5 & 7 \\
\hline 0901 & 1 & 0 & 1 \\
\hline 1001 & 0 & 0 & 0 \\
\hline 1002 & 1 & 0 & 1 \\
\hline 1003 & 0 & 0 & 0 \\
\hline 1004 & 0 & 2 & 2 \\
\hline 1005 & 0 & 3 & 3 \\
\hline 1006 & 0 & 0 & 0 \\
\hline 1007 & 4 & 5 & 9 \\
\hline 1008 & 2 & 0 & 2 \\
\hline 1009 & 1 & 1 & 2 \\
\hline 1010 & 1 & 1 & 2 \\
\hline 1011 & 1 & 6 & 7 \\
\hline
\end{tabular}


TABLE 5.4 (Cont'd)

\begin{tabular}{|c|c|c|c|}
\hline ASA & Load Growth & Replacement & Total \\
\hline 1101 & 2 & 2 & 4 \\
\hline 1102 & 2 & 0 & 2 \\
\hline 1103 & 1 & 2 & 3 \\
\hline 1104 & 4 & 6 & 10 \\
\hline 1105 & 2 & 4 & 6 \\
\hline 1106 & 1 & 1 & 2 \\
\hline 1107 & 0 & 5 & 5 \\
\hline 1201 & 0 & 4 & 4 \\
\hline 1202 & 4 & 10 & 14 \\
\hline 1203 & 1 & 9 & 10 \\
\hline 1204 & 0 & 4 & 4 \\
\hline 1205 & 2 & 4 & 6 \\
\hline 1301 & 0 & 0 & 0 \\
\hline 1302 & 1 & 0 & 1 \\
\hline 1303 & 1 & 0 & 1 \\
\hline 1304 & 1 & 0 & 1 \\
\hline 1305 & 1 & 0 & 1 \\
\hline 1401 & 0 & 4 & 4 \\
\hline 1402 & 0 & 3 & 3 \\
\hline 1403 & 0 & 6 & 6 \\
\hline 1501 & 1 & 1 & 2 \\
\hline 1502 & 0 & 4 & 4 \\
\hline 1503 & 3 & 3 & 6 \\
\hline 1601 & 2 & 0 & 2 \\
\hline 1602 & 0 & 0 & 0 \\
\hline 1603 & 0 & 0 & 0 \\
\hline 1604 & 0 & 1 & 1 \\
\hline 1701 & 0 & 2 & 2 \\
\hline 1702 & 0 & 4 & 4 \\
\hline 1703 & 0 & 4 & 4 \\
\hline
\end{tabular}


TABLE 5.4 (Cont'd)

\begin{tabular}{cccc} 
ASA & Load Growth & Replacement & Total \\
\cline { 2 - 4 } 1704 & 0 & 1 & 1 \\
1705 & 2 & 4 & 6 \\
1706 & 0 & 0 & 0 \\
1707 & 0 & 0 & 0 \\
1801 & 2 & 1 & 3 \\
1802 & 2 & 3 & 5 \\
1803 & 1 & 3 & 4 \\
1804 & 3 & 1 & 4 \\
1805 & 0 & 1 & 1 \\
1806 & 7 & 7 & 14 \\
1807 & 0 & 0 & 0
\end{tabular}


TABLE 5.5

CAPACITY ADDITIONS: LOAD GROWTH AND REPLACEMENT 2000 TO 2020 (GW) MEDIAN GROWTH SCENARIO

\begin{tabular}{|c|c|c|c|}
\hline ASA & $\begin{array}{l}\text { Load Growth } \\
\text { Requirements } \\
\end{array}$ & $\begin{array}{l}\text { Replacement } \\
\text { Requirements } \\
\end{array}$ & Total \\
\hline 0101 & 0 & 1 & 1 \\
\hline 0102 & 0 & 2 & 2 \\
\hline 0103 & 3 & 5 & 8 \\
\hline 0104 & 3 & 3 & 6 \\
\hline 0105 & 1 & 2 & 3 \\
\hline 0106 & 0 & 0 & 0 \\
\hline 0201 & 1 & 3 & 4 \\
\hline 0202 & 7 & 11 & 18 \\
\hline 0203 & 6 & 8 & 14 \\
\hline 0204 & 2 & 10 & 12 \\
\hline 0205 & 6 & 6 & 12 \\
\hline 0206 & 3 & 4 & 7 \\
\hline 0301 & 7 & 9 & 16 \\
\hline 0302 & 6 & 7 & 13 \\
\hline 0303 & 7 & 8 & 15 \\
\hline 0304 & 11 & 11 & 22 \\
\hline 0305 & 11 & 5 & 16 \\
\hline 0306 & 6 & 3 & 9 \\
\hline 0307 & 3 & 8 & 11 \\
\hline 0308 & 2 & 3 & 5 \\
\hline 0309 & 2 & 1 & 3 \\
\hline 0401 & 0 & 1 & 1 \\
\hline 0402 & 1 & 3 & 4 \\
\hline 0403 & 4 & 4 & 8 \\
\hline 0404 & 6 & 7 & 13 \\
\hline 0405 & 3 & 2 & 5 \\
\hline 0406 & 10 & 4 & 14 \\
\hline 0407 & 6 & 4 & 10 \\
\hline
\end{tabular}


TABLE 5.5 (Cont'd)

\begin{tabular}{|c|c|c|c|}
\hline ASA & $\begin{array}{l}\text { Load Growth } \\
\text { Requirements }\end{array}$ & $\begin{array}{l}\text { Rep lacement } \\
\text { Requirements } \\
\end{array}$ & Total \\
\hline 0408 & 1 & 2 & 3 \\
\hline 0501 & 3 & 12 & 15 \\
\hline 0502 & 4 & 12 & 16 \\
\hline 0503 & 5 & 1 & 6 \\
\hline 0504 & 1 & 4 & 5 \\
\hline 0505 & 7 & 7 & 14 \\
\hline 0506 & 6 & 7 & 13 \\
\hline 0507 & 2 & 4 & 6 \\
\hline 0601 & 4 & 3 & 7 \\
\hline 0602 & 1 & 5 & 6 \\
\hline 0701 & 6 & 5 & 11 \\
\hline 0702 & 3 & 3 & 6 \\
\hline 0703 & 7 & 5 & 12 \\
\hline 0704 & 10 & 13 & 23 \\
\hline 0705 & 3 & 6 & 9 \\
\hline 0801 & 6 & 3 & 9 \\
\hline 0802 & 4 & 5 & 9 \\
\hline 0803 & 2 & 5 & 7 \\
\hline 0901 & 1 & 0 & 1 \\
\hline 1001 & 0 & 0 & 0 \\
\hline 1002 & 1 & 0 & 1 \\
\hline 1003 & 0 & 0 & 0 \\
\hline 1004 & 1 & 2 & 3 \\
\hline 1005 & 0 & 3 & 3 \\
\hline 1006 & 1 & 0 & 1 \\
\hline 1007 & 5 & 5 & 10 \\
\hline 1008 & 1 & 0 & 1 \\
\hline 1009 & 2 & 1 & 3 \\
\hline 1010 & 3 & 1 & 4 \\
\hline 1011 & 3 & 6 & 9 \\
\hline
\end{tabular}


TABLE 5.5 (Cont'd)

\begin{tabular}{|c|c|c|c|}
\hline ASA & $\begin{array}{l}\text { Load Growth } \\
\text { Requirements }\end{array}$ & $\begin{array}{l}\text { Replacement } \\
\text { Requirements }\end{array}$ & Total \\
\hline 1101 & 3 & 2 & 5 \\
\hline 1102 & 3 & 0 & 3 \\
\hline 1103 & 4 & 2 & 6 \\
\hline 1104 & 5 & 6 & 11 \\
\hline 1105 & 3 & 4 & 7 \\
\hline 1106 & 2 & 1 & 3 \\
\hline 1107 & 1 & 5 & 6 \\
\hline 1201 & 1 & 4 & 5 \\
\hline 1202 & 6 & 10 & 16 \\
\hline 1203 & 3 & 9 & 12 \\
\hline 1204 & 1 & 4 & 5 \\
\hline 1205 & 4 & 4 & 8 \\
\hline 1301 & 1 & 0 & 1 \\
\hline 1302 & 1 & 0 & 1 \\
\hline 1303 & 1 & 0 & 1 \\
\hline 1304 & 1 & 0 & 1 \\
\hline 1305 & 2 & 0 & 2 \\
\hline 1401 & 0 & 4 & 4 \\
\hline 1402 & 1 & 3 & 4 \\
\hline 1403 & 0 & 6 & 6 \\
\hline 1501 & 2 & 1 & 3 \\
\hline 1502 & 1 & 4 & 5 \\
\hline 1503 & 5 & 3 & 8 \\
\hline 1601 & 2 & 0 & 2 \\
\hline 1602 & 0 & 0 & 0 \\
\hline 1603 & 1 & 0 & 1 \\
\hline 1604 & 1 & 1 & 2 \\
\hline 1701 & 0 & 2 & 2 \\
\hline 1702 & 0 & 4 & 4 \\
\hline 1703 & -1 & 4 & 3 \\
\hline
\end{tabular}


TABLE 5.5 (Cont'd)

\begin{tabular}{|c|c|c|c|}
\hline ASA & $\begin{array}{l}\text { Load Growth } \\
\text { Requirements }\end{array}$ & $\begin{array}{l}\text { Rep lacement } \\
\text { Requirements }\end{array}$ & Total \\
\hline 1704 & 0 & 1 & 1 \\
\hline 1705 & 3 & 4 & 7 \\
\hline 1706 & 3 & 0 & 3 \\
\hline 1707 & 0 & 0 & 0 \\
\hline 1801 & 1 & 1 & 2 \\
\hline 1802 & 3 & 3 & 6 \\
\hline 1803 & 4 & 3 & 7 \\
\hline 1804 & 6 & 1 & 7 \\
\hline 1805 & 1 & 1 & 2 \\
\hline 1806 & 15 & 7 & 22 \\
\hline 1807 & 1 & 0 & 1 \\
\hline
\end{tabular}

$5-23$ 
TABLE 5.6

CAPACITY ADDITIONS: LOAD GROWTH AND REPLACEMENT 2000 TO 2020 (GW) HIGH GROWTH SCENARIO

\begin{tabular}{|c|c|c|c|}
\hline ASA & Load Growth & Replacement & Total \\
\hline 0101 & 1 & 1 & 2 \\
\hline 0102 & 0 & 2 & 2 \\
\hline 0103 & 5 & 5 & 10 \\
\hline 0104 & 5 & 3 & 8 \\
\hline 0105 & 3 & 2 & 5 \\
\hline 0106 & 0 & 0 & 0 \\
\hline 0201 & 3 & 3 & 6 \\
\hline 0202 & 16 & 11 & 27 \\
\hline 0203 & 12 & 8 & 20 \\
\hline 0204 & 5 & 10 & 15 \\
\hline 0205 & 13 & 6 & 19 \\
\hline 0206 & 6 & 4 & 10 \\
\hline 0301 & 13 & 9 & 22 \\
\hline 0302 & 16 & 7 & 23 \\
\hline 0303 & 11 & 8 & 19 \\
\hline 0304 & 19 & 11 & 30 \\
\hline 0305 & 18 & 5 & 23 \\
\hline 0306 & 9 & 3 & 12 \\
\hline 0307 & 7 & 8 & 15 \\
\hline 0308 & 4 & 3 & 7 \\
\hline 0309 & 3 & 1 & 4 \\
\hline 0401 & 0 & 1 & 1 \\
\hline 0402 & 3 & 3 & 6 \\
\hline 0403 & 7 & 4 & 11 \\
\hline 0404 & 10 & 7 & 17 \\
\hline 0405 & 5 & 2 & 7 \\
\hline 0406 & 12 & 4 & 16 \\
\hline 0407 & 12 & 4 & 16 \\
\hline 0408 & 1 & 2 & 3 \\
\hline
\end{tabular}


TABLE 5.6 (Cont'd)

\begin{tabular}{|c|c|c|c|}
\hline ASA & Load Growth & Rep lacement & Total \\
\hline 0501 & 7 & 12 & 19 \\
\hline 0502 & 12 & 12 & 24 \\
\hline 0503 & 14 & 1 & 15 \\
\hline 0504 & 3 & 4 & 7 \\
\hline 0505 & 11 & 7 & 18 \\
\hline 0506 & 12 & 7 & 19 \\
\hline 0507 & 4 & 4 & 8 \\
\hline 0601 & 7 & 3 & 10 \\
\hline 0602 & 2 & 5 & 7 \\
\hline 0701 & 9 & 5 & 14 \\
\hline 0702 & 4 & 3 & 7 \\
\hline 0703 & 10 & 5 & 15 \\
\hline 0704 & 19 & 13 & 22 \\
\hline 0705 & 5 & 6 & 11 \\
\hline 0801 & 9 & 3 & 12 \\
\hline 0802 & 6 & 5 & 11 \\
\hline 0803 & 4 & 5 & 9 \\
\hline 0901 & 1 & 0 & 1 \\
\hline 1001 & 0 & 0 & 0 \\
\hline 1002 & 0 & 0 & 0 \\
\hline 1003 & 0 & 0 & 0 \\
\hline 1004 & 2 & 2 & 4 \\
\hline 1005 & 1 & 3 & 4 \\
\hline 1006 & 2 & 0 & 2 \\
\hline 1007 & 7 & 5 & 12 \\
\hline 1008 & 1 & 0 & 1 \\
\hline 1009 & 4 & 1 & 5 \\
\hline 1010 & 4 & 1 & 5 \\
\hline 1011 & 3 & 6 & 9 \\
\hline 1101 & 4 & 2 & 6 \\
\hline
\end{tabular}


TABLE 5.6 (Cont'd)

\begin{tabular}{|c|c|c|c|}
\hline ASA & Load Growth & Rep lacement & Total \\
\hline 1102 & 4 & 0 & 4 \\
\hline 1103 & 5 & 2 & 7 \\
\hline 1004 & 10 & 6 & 16 \\
\hline 1005 & 6 & 4 & 10 \\
\hline 1106 & 3 & 1 & 4 \\
\hline 1107 & 3 & 5 & 8 \\
\hline 1201 & 3 & 4 & 7 \\
\hline 1202 & 14 & 10 & 24 \\
\hline 1203 & 5 & 9 & 14 \\
\hline 1204 & 1 & 4 & 5 \\
\hline 1205 & 7 & 4 & 11 \\
\hline 1301 & 2 & 0 & 2 \\
\hline 1302 & 3 & 0 & 3 \\
\hline 1303 & 1 & 0 & 1 \\
\hline 1304 & 0 & 0 & 0 \\
\hline 1305 & 2 & 0 & 2 \\
\hline 1401 & 0 & 4 & 4 \\
\hline 1402 & 2 & 3 & 5 \\
\hline 1403 & 0 & 6 & 6 \\
\hline 1501 & 2 & 1 & 3 \\
\hline 1502 & 3 & 4 & 7 \\
\hline 1503 & 9 & 3 & 12 \\
\hline 1601 & 2 & 0 & 2 \\
\hline 1602 & 0 & 0 & 0 \\
\hline 1603 & 2 & 0 & 2 \\
\hline 1604 & 2 & 1 & 3 \\
\hline 1701 & 1 & 2 & 3 \\
\hline 1702 & 1 & 4 & 5 \\
\hline 1703 & 0 & 4 & 4 \\
\hline 1704 & 1 & 1 & 2 \\
\hline
\end{tabular}


TABLE 5.6 (Cont'd)

\begin{tabular}{lccc} 
ASA & Load Growth & & Replacement \\
\cline { 3 - 4 } 1705 & 6 & 4 & Total \\
1706 & 5 & 0 & 10 \\
1707 & 0 & 0 & 5 \\
1801 & 1 & 1 & 0 \\
1802 & 4 & 3 & 2 \\
1803 & 5 & 3 & 7 \\
1804 & 12 & 1 & 8 \\
1805 & 3 & 1 & 13 \\
1806 & 28 & 7 & 4 \\
1807 & 3 & 0 & 35
\end{tabular}


facilities were sited in the Upper Missouri River Basin in the year 2000. For the accelerated case, a total of 33 facilities were sited in the Basin.

For the base case scenario, 11 facilities were sited on the main steam Missouri River in North Dakota, four facilities each on the Lower Yellowstone River in Montana and the Powder and Tongue River in Wyoming and one each on the Upper Yellowstone River in Montana and the Powder and Tongue River in Montana. Fifteen of the facilities were assumed to be coal gasification plants and the remaining six were assumed to be liquefaction plants.

For the accelerated case scenario, 12 facilities were located on the main stem Missouri River in North Dakota, nine facilities on the Powder and Tongue Rivers in Wyoming, seven facilities on the Powder and Tongue Rivers in Montana, two each on the Upper Yellowstone River in Montana and the Lower Yellowstone River in Montana, and a single plant on the Missouri River in South Dakota. Twenty-two of the facilities were assumed to be coal gasification plants and nine of the facilities were assumed to be coal liquefaction plants.

In addition to the Upper Missouri River Basin, it was assumed that coal synfuel facilities would be located in the Appalachian coal region and the central interior coal region. $0 i l$ shale synfuel facilities would be located in the Upper Colorado River Basin.

In the Upper Missouri River Basin, it was assumed that major synfuel facilities would be located in ASA 1004 and ASA 1005. ASA 1004 contains the largest known resource of low sulfur strippable subbituminous coal and lignite in the country. The Powder River Basin is located in ASA 1005 and contains large reserves of subbituminous coal. In the Appalachian coal region, it was assumed that synfuel facilities would be located in ASAs 0203, 0204, and 0206. Substantial reserves of both anthracite and bituminous coal are located in ASAs 0203, 0204, and 0206. Vast coal reserves exist throughout region 5. Region 5 contains the major coal producing states, Kentucky, Illinois, and Ohio and it was assumed the pattern of use would continue. 
The southeast contains large reserves of bituminous coal. The extent to which these resources would be developed in support of synfuel facilities is unknown and was not speculated.

The largest resource of oil shale in the United States is located within ASA 1401 and ASA 1402. The potentially recoverable oil in the region is estimated to exceed 1 trillion barrels.

It was arbitrarily assumed that the growth of the synfuel industry would be uniform across four major resource areas, the Upper Missouri River Basin, the Upper Colorado River Basin, the Midwestern Interior, and the Northern Appalachian Mountains. As a result, for the low growth scenario which assumes an installed capacity of approximately 4 quads in the year 2000, 15 facilities were assigned to each of the regions. For the high growth scenario which assumes an installed capacity of 16 quads in the year 2020, 60 facilities were assigned to each of the regions.

A summary of the forecasted installed capacity for each region is provided in Table 5.7.

\subsection{REQUIREMENTS FOR DRY COOLING}

Generally speaking, it was assumed that in water-short ASAs, dry or peak shaved wet/dry cooling (advanced cooling) will be required for cooling both steam electric power plants and synfuel facilities.

In Section 4 (Water Resources) of the report, 32 ASAs were identified as having constant or periodic deficits in surface and groundwater supply. Most of the ASAs are presently experiencing water shortages. The water shortage issue is acute in several states in the southwestern United States. In Arizona, the available surface water was depleted several decades ago, and since that time, development has been supported by the use of groundwater resources. At the present time, a serious groundwater overdraft exists in and around Phoenix. Furthermore, groundwater overdrafts are common 
TABLE 5.7

A SUMMARY OF SYNFUEL FACILITIES

(Number of Units)

Year 2000 Forecast Year 2020 Forecast

\begin{tabular}{|c|c|c|c|c|c|}
\hline Region & Type & 4 Quads & 8 Quads & 8 quads & 16 quads \\
\hline Upper Colorado & oil Shale* & 15 & 30 & 30 & 60 \\
\hline Upper Missouri & Coal $* \star$ & 15 & 30 & 30 & 60 \\
\hline Midwest Interior & Coal** & 15 & 30 & 30 & 60 \\
\hline Appalachian & $\operatorname{Coa} 7 * \star$ & 15 & 30 & 30 & 60 \\
\hline
\end{tabular}

* Liquid Product

$\star \star 50 \%$ Liquid Product, $50 \%$ Gaseous Product 
throughout most of the southwest, which has experienced major population and economic growth (i.e., Denver, Las Vegas, San Joaquin Valley, etc). It must be recognized that water problems associated with overuse do not appear overnight, and once recognized and accepted, are not corrected instantaneously. Water resource programs and management are best described as molded by water law, legislation, and societal priorities. An existing pattern of usage reflects the integration of these considerations. Although there undoubtably will be some water available for the purpose of cooling thermal electric power generation and synfuel facilities in water-short areas of the country, it was assumed that in such areas, higher priority uses of water will continue to have precedence over lower priority uses such as cooling.

For purposes of planning, an attempt was made to identify an upper bound on the requirements for advanced cooling technology, knowing that some relaxation of the condition will ultimately result in the years ahead. For each energy growth scenario, it was assumed that each energy facility sited (constructed) in water-short ASAs would require an advanced form of cooling.

Tables 5.8, 5.9, and 5.10 summarize the advanced cooling requirement for energy facilities constructed during the 20 -year forecast period. Table 5.8 summarizes the advanced cooling requirement over the forecast period using the low growth energy scenario described previously. For the low growth scenario, the range in number of steam electric facilities requiring advanced cooling ranges from 40 to $110 \mathrm{GW}$ of installed capacity. For this scenario, 14 synfuel facilities, each with a capacity of $250 \times 10^{9}$ Btu's per day, are forecasted to require advanced cooling.

Table 5.9 summarizes the advanced cooling requirements over the forecast period using the median growth energy scenario. For the median growth scenario, the installed capacity requiring advanced cooling is forecasted to range from 74 to $144 \mathrm{GW}$. For that scenario, 38 synfuel facilities will require advanced cooling. 
TABLE 5.8

A SUMMARY: ADVANCED COOLING REQUIREMENTS AND ESTIMATED WATER SAVINGS (LOW GROWTH SCENARIO)

\begin{tabular}{|c|c|c|c|c|c|c|c|}
\hline \multirow[b]{2}{*}{ ASA } & \multicolumn{3}{|c|}{ Steam Electric (GW) } & \multicolumn{2}{|c|}{$\begin{array}{l}\text { Synfuel Facilities } \\
(250 \times 109 \text { Btu/Day })\end{array}$} & \multicolumn{2}{|c|}{ Water Saving (mgd) } \\
\hline & Replacement & Load & Growth & Coal & $0 \mathrm{il}$ & New & Replace \\
\hline 0403 & 4 & & 3 & 0 & 0 & 60 & 80 \\
\hline 1002 & 0 & & 1 & 0 & 0 & 20 & 0 \\
\hline 1004 & 2 & & 0 & 7 & 0 & 40 & 40 \\
\hline 1007 & 5 & & 4 & 0 & 0 & 0 & 40 \\
\hline 1008 & 0 & & 2 & 0 & 0 & 0 & 40 \\
\hline 1010 & 1 & & 1 & 0 & 0 & 20 & 20 \\
\hline 1102 & 0 & & 2 & 0 & 0 & 40 & 0 \\
\hline 1103 & 2 & & 1 & 0 & 0 & 20 & 40 \\
\hline 1105 & 4 & & 2 & 0 & 0 & 40 & 80 \\
\hline 1106 & 1 & & 1 & 0 & 0 & 20 & 20 \\
\hline 1202 & 10 & & 4 & 0 & 0 & 80 & 200 \\
\hline 1203 & 9 & & 1 & 0 & 0 & 20 & 80 \\
\hline 1204 & 4 & & 0 & 0 & 0 & 0 & 80 \\
\hline 1301 & 0 & & 0 & 0 & 0 & 0 & 0 \\
\hline 1302 & 0 & & 1 & 0 & 0 & 20 & 0 \\
\hline 1303,1304 & 0 & & 2 & 0 & 0 & 40 & 0 \\
\hline 1305 & 0 & & 1 & 0 & 0 & 20 & 0 \\
\hline 1401 & 4 & & 0 & 0 & 7 & 30 & 80 \\
\hline 1501 & 1 & & 1 & 0 & 0 & 20 & 20 \\
\hline 1502 & 4 & & 0 & 0 & 0 & 0 & 80 \\
\hline 1503 & 3 & & 3 & 0 & 0 & 60 & 60 \\
\hline 1601 & 0 & & 2 & 0 & 0 & 40 & 0 \\
\hline 1602 & 0 & & 0 & 0 & 0 & 0 & 0 \\
\hline 1603 & 0 & & 0 & 0 & 0 & 0 & 0 \\
\hline 1604 & 1 & & 0 & 0 & 0 & 0 & 20 \\
\hline 1703 & 4 & & 0 & 0 & 0 & 0 & 80 \\
\hline 1707 & 0 & & 0 & 0 & 0 & 0 & 0 \\
\hline
\end{tabular}


TABLE 5.8 (Cont'd)

\begin{tabular}{|c|c|c|c|c|c|c|}
\hline \multirow[b]{2}{*}{ ASA } & \multicolumn{2}{|c|}{ Steam Electric (GW) } & \multicolumn{2}{|c|}{$\begin{array}{l}\text { Synfuel Facilities } \\
\left(250 \times 10^{9} \text { Btu/Day }\right)\end{array}$} & \multicolumn{2}{|c|}{ Water Saving (mgd) } \\
\hline & Replacement & Load Growth & Coal & $0 i 1$ & New & Replace \\
\hline 1803 & 3 & 1 & 0 & 0 & 20 & 60 \\
\hline 1805 & 1 & 0 & 0 & 0 & 0 & 20 \\
\hline 1806 & 7 & 7 & 0 & 0 & 140 & 140 \\
\hline 1807 & 0 & 0 & 0 & 0 & 0 & 0 \\
\hline
\end{tabular}


TABLE 5.9

A SUMMARY: ADVANCED COOLING REQUIREMENTS AND ESTIMATED WATER SAVINGS-(MEDIAN GROWTH SCENARIO)

\begin{tabular}{|c|c|c|c|c|c|c|c|}
\hline \multirow[b]{2}{*}{ ASA } & \multicolumn{3}{|c|}{ Steam Electric (GW) } & \multicolumn{2}{|c|}{$\begin{array}{l}\text { Synfuel Facilities } \\
\left(250 \times 10^{9} \text { Btu/day }\right)\end{array}$} & \multicolumn{2}{|c|}{ Water Saving (mgd) } \\
\hline & Rep lacement & Load & Growth & Coal & $0 i 1$ & New & Replace \\
\hline 0403 & 4 & & 4 & 0 & 0 & 80 & 80 \\
\hline 1002 & 0 & & 1 & 0 & 0 & 20 & 0 \\
\hline 1004 & 2 & & 1 & 19 & 0 & 130 & 40 \\
\hline 1007 & 5 & & 5 & 0 & 0 & 100 & 100 \\
\hline 1008 & 0 & & 1 & 0 & 0 & 20 & 0 \\
\hline 1010 & 1 & & 2 & 0 & 0 & 40 & 20 \\
\hline 1102 & 0 & & 3 & 0 & 0 & 60 & 0 \\
\hline 1103 & 2 & & 4 & 0 & 0 & 80 & 40 \\
\hline 1105 & 4 & & 3 & 0 & 0 & 60 & 80 \\
\hline 1106 & 1 & & 2 & 0 & 0 & 40 & 20 \\
\hline 1202 & 10 & & 6 & 0 & 0 & 120 & 200 \\
\hline 1203 & 9 & & 3 & 0 & 0 & 60 & 180 \\
\hline 1204 & 4 & & 1 & 0 & 0 & 20 & 80 \\
\hline 1301 & 0 & & 1 & 0 & 0 & 20 & 0 \\
\hline 1302 & 0 & & 1 & 0 & 0 & 20 & 0 \\
\hline 1303,1304 & 0 & & 2 & 0 & 0 & 40 & 0 \\
\hline 1305 & 0 & & 2 & 0 & 0 & 40 & 0 \\
\hline 1401 & 4 & & 0 & 0 & 19 & 80 & 80 \\
\hline 1501 & 1 & & 2 & 0 & 0 & 40 & 20 \\
\hline 1502 & 4 & & 1 & 0 & 0 & 20 & 80 \\
\hline 1503 & 3 & & 5 & 0 & 0 & 100 & 60 \\
\hline 1601 & 0 & & 2 & 0 & 0 & 40 & 0 \\
\hline 1602 & 0 & & 0 & 0 & 0 & 0 & 0 \\
\hline 1603 & 0 & & 1 & 0 & 0 & 20 & 0 \\
\hline 1604 & 1 & & 1 & 0 & 0 & 20 & 20 \\
\hline 1703 & 4 & & -1 & 0 & 0 & -20 & 80 \\
\hline
\end{tabular}




\section{TABLE 5.9 (Cont'd)}

\begin{tabular}{|c|c|c|c|c|c|c|}
\hline \multirow[b]{2}{*}{ ASA } & \multicolumn{2}{|c|}{ Steam Electric (GW) } & \multicolumn{2}{|c|}{$\begin{array}{l}\text { Synfuel Facilities } \\
\left(250 \times 10^{9} \text { Btu/day }\right)\end{array}$} & \multicolumn{2}{|c|}{ Water Saving (mgd) } \\
\hline & Replacement & Load Growth & Coal & $0 i 1$ & New & Replace \\
\hline 1707 & 0 & 0 & 0 & 0 & 0 & 0 \\
\hline 1803 & 3 & 4 & 0 & 0 & 80 & 60 \\
\hline 1805 & 1 & 1 & 0 & 0 & 20 & 20 \\
\hline 1806 & 7 & 15 & 0 & 0 & 300 & 140 \\
\hline 1807 & 0 & 1 & 0 & 0 & 20 & 0 \\
\hline
\end{tabular}


TABLE 5.10

A SUMMARY: ADVANCED COOLING REQUIREMENTS AND ESTIMATED WATER SAVINGS-( HIGH GROWTH SCENARIO)

\begin{tabular}{|c|c|c|c|c|c|c|}
\hline \multirow[b]{2}{*}{ ASA } & \multicolumn{2}{|c|}{ Steam Electric (GW) } & \multicolumn{2}{|c|}{$\begin{array}{l}\text { Synfuel Facilities } \\
(250 \times 109 \text { Btu/day })\end{array}$} & \multicolumn{2}{|c|}{ Water Saving (mgd) } \\
\hline & Replacement & Load Growth & Coal & $0 i 1$ & New & Replace \\
\hline 403 & 4 & 7 & 0 & 0 & 140 & 80 \\
\hline 1002 & 0 & 0 & 0 & 0 & 0 & 0 \\
\hline 1004 & 2 & 2 & 30 & 0 & 211 & 40 \\
\hline 1007 & 5 & 7 & 0 & 0 & 140 & 100 \\
\hline 1008 & 0 & 1 & 0 & 0 & 20 & 0 \\
\hline 1010 & 1 & 4 & 0 & 0 & 80 & 20 \\
\hline 1102 & 0 & 4 & 0 & 0 & 80 & 0 \\
\hline 1103 & 2 & 5 & 0 & 0 & 100 & 40 \\
\hline 1105 & 4 & 6 & 0 & 0 & 120 & 80 \\
\hline 1106 & 1 & 3 & 0 & 0 & 60 & 20 \\
\hline 1202 & 10 & 14 & 0 & 0 & 280 & 200 \\
\hline 1203 & 9 & 5 & 0 & 0 & 100 & 180 \\
\hline 1204 & 4 & 1 & 0 & 0 & 20 & 80 \\
\hline 1301 & 0 & 2 & 0 & 0 & 40 & 0 \\
\hline 1302 & 0 & 3 & 0 & 0 & 60 & 0 \\
\hline 1303,1304 & 0 & 1 & 0 & 0 & 20 & 0 \\
\hline 1305 & 0 & 2 & 0 & 0 & 40 & 0 \\
\hline 1401 & 4 & 0 & 0 & 30 & 126 & 80 \\
\hline 1501 & 1 & 2 & 0 & 0 & 40 & 0 \\
\hline 1502 & 4 & 3 & 0 & 0 & 60 & 80 \\
\hline 1503 & 3 & 9 & 0 & 0 & 180 & 60 \\
\hline 1601 & 0 & 2 & 0 & 0 & 40 & 0 \\
\hline 1602 & 0 & 0 & 0 & 0 & 0 & 0 \\
\hline 1603 & 0 & 2 & 0 & 0 & 40 & 0 \\
\hline 1604 & 1 & 2 & 0 & 0 & 40 & 20 \\
\hline 1703 & 4 & 0 & 0 & 0 & 0 & 80 \\
\hline
\end{tabular}


TABLE 5.10 (Cont'd)

\begin{tabular}{|c|c|c|c|c|c|c|}
\hline \multirow[b]{2}{*}{ ASA } & \multicolumn{2}{|c|}{ Steam Electric (GW) } & \multicolumn{2}{|c|}{$\begin{array}{l}\text { Synfuel Facilities } \\
(250 \times 109 \mathrm{Btu} / \mathrm{day})\end{array}$} & \multicolumn{2}{|c|}{ Water Saving (mgd) } \\
\hline & Replacement & Load Growth & Coal & $0 i 1$ & New & Replace \\
\hline 1707 & 0 & 0 & 0 & 0 & 0 & 0 \\
\hline 1803 & 3 & 5 & 0 & 0 & 100 & 60 \\
\hline 1805 & 1 & 3 & 0 & 0 & 60 & 20 \\
\hline 1806 & 7 & 28 & 0 & 0 & 560 & 140 \\
\hline 1807 & 0 & 3 & 0 & 0 & 60 & 0 \\
\hline
\end{tabular}


Table 5.10 summarizes the advanced cooling requirements for the $h$ igh energy growth scenario. For this scenario, 126 to $196 \mathrm{GW}$ 's of installed electrical generating capacity are forecasted to require advanced cooling technology. The total number of synfuel facilities requiring advanced cooling technology is 60 .

An estimate of water saving for each scenario is provided. Estimated water savings in mgd are based upon assigning an average usage of $20 \mathrm{mgd}$ for each GW of steam electric power plant constructed, $5.7 \mathrm{mgd}$ for each $250 \times 10^{9}$ Btu/day coal-supported synfuel facility constructed, and $4.2 \mathrm{mgd}$ for each oil shale synfuel facility constructed. A credit for replacement capacity was assumed, since this reflected a consumptive use water requirement previousiy committed.

\subsection{SURVEY: STEAM ELECTRIC POWER PLANT COOLING}

During the 1980's, approximately $233 \mathrm{GW}$ of capacity is scheduled to be installed in the contiguous United States. $(12,13)$ A phone survey of power plant cooling for this scheduled capacity in the water-short regions of the southwestern United States was performed. A summary of the results of the survey is provided in this section of the report. This discussion is organized by Electric Power Region. Figure 5.1 shows the location of the Electic Power Regions. A discussion of power plant cooling scheduled to be installed during the 1980 's for Electric Power Regions 22, 23, 24, 26, 27 , and 28 is included.

\subsubsection{Electric Power Region 22}

Electric Power Region 22 covers the state of Oklahoma, and portions of Arkansas, Louisiana, New Mexico and Texas. The region has been predominantly a natural gas burning area, although the more recent trend is towards an increased use of coal. The installed capacity in January 1980 was approximately $18 \mathrm{GW}$ and the planned capacity additions during the 1980 's total approximately $10 \mathrm{GW}$, including $9.2 \mathrm{GW}$ of coal and $0.8 \mathrm{GW}$ nuclear. 


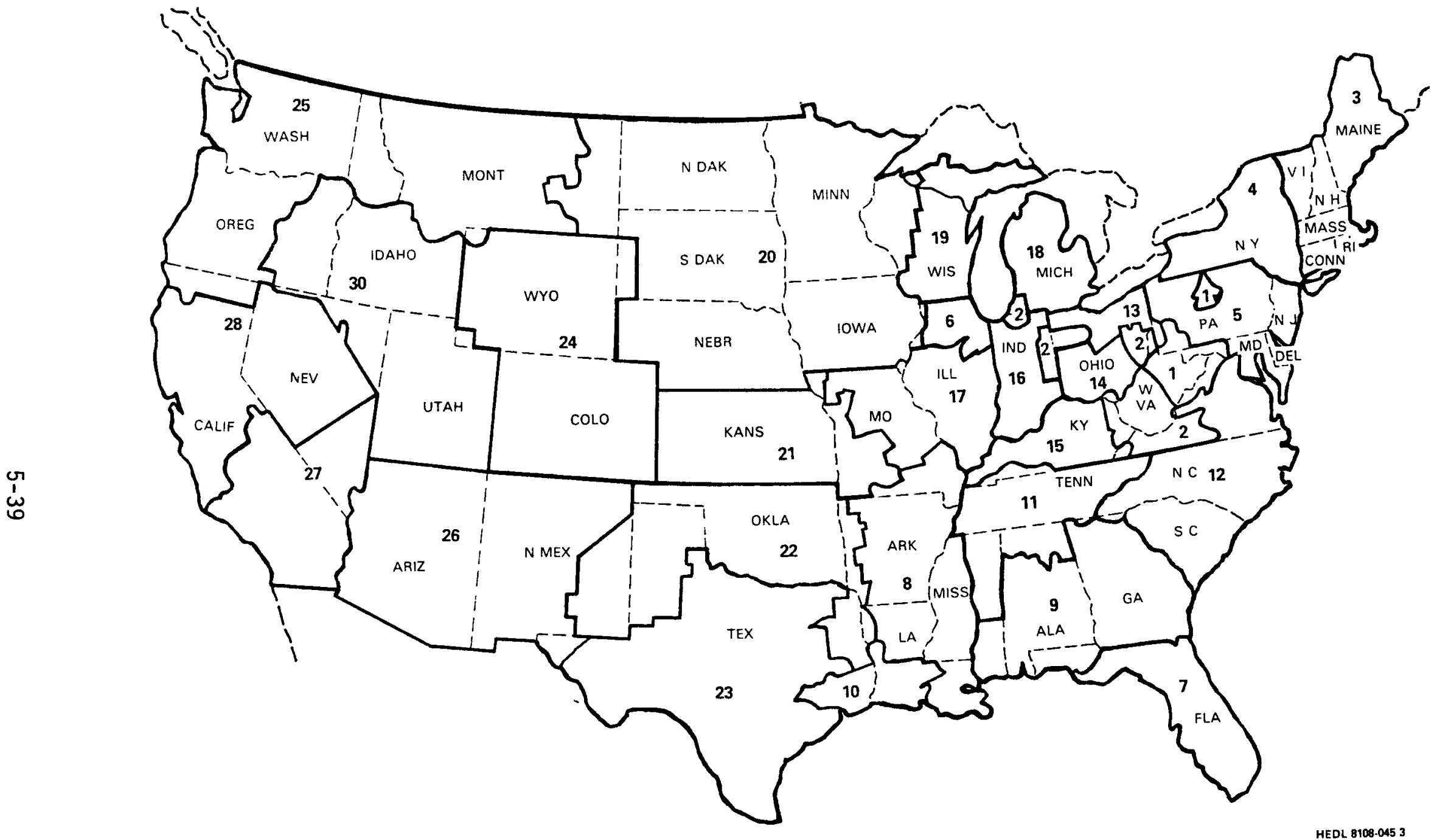

FIGURE 5.1. Electric Power Regions in the Contiguous United States. 
This Electric Power Region interconnects with Electric Power Regions 21 and 8. Electric Power Region 22 is interconnected to the Middle South Group (Electric Power Region 21) with a 500-kV transmission line, and the Missouri-Kansas group (Electric Power Region 8) with two 345-kV transmission lines.

Power plant cooling system design is forecasted to remain basically the same during the 1980's. Steam electric power plants in Oklahoma rely heavily upon the use of wet evaporative cooling towers. Makeup water in the central and eastern parts of the electric region will be provided by surface waters via lakes and rivers, whereas in the west, makeup water will be provided by wells, waste water, and/or surface water.

Approximately $1545 \mathrm{MW}$ in the form of three 515-MW coal-fired units will be sited at the Sooner power station near Oklahoma City, Oklahoma. These units will be cooled using a 500-acre man-made lake. Water will be pumped from the Arkansas river to form the lake. Approximately $900 \mathrm{MW}$ of coal-fired capacity will become available when units 3 and 4 of the Northeastern Power Station are completed. Units 3 and 4 will be cooled using wet evaporative cooling towers and their makeup will be provided from Lake Dolagah. The Muskogee unit 6 coal-fired plant will be cooled using wet evaporative cooling towers, as will units 1 and 2 of the Southwest power station. The Moreland power station is cooled using wet evaporative towers and the makeup water is obtained from wells. The Lawton combined cycle power plant is cooled using evaporative towers and the makeup water is obtained from Lawton municipal waste water.

\subsubsection{Electric Power Region 23}

This region includes all of Texas except the extreme eastern border, the El Paso area in the extreme west, and the northwestern "panhandle." The members of the Electric Reliability Council of Texas (ERCOT) supply electric power only within the state of Texas. Although Texas is presently isolated electrically from other Electric Regions of the country, there is a study 
underway to test the feasibility of connecting ERCOT with the Southwest Power Pool Reliability Council (SPPC).

Historically, this has been an area which has experienced a high growth rate. The annual compound rate factor during the period 1950 through 1976 exceeded $10 \%$ for both peak demand and energy generated. The installed capacity in January 1980 was approximately $40 \mathrm{GW}$ and is forecasted to increase to over $60 \mathrm{GW}$ by $1990(12, i 3)$ In terms of energy resource utilization, over the years the area has been heavily dependent upon the use of natural gas and oil for the production of steam electric energy. However, this pattern will change over the ten year period (1980 to 1989); all major capacity additions will be fueled by either coal or lignite, or will be nuclear.

Power plant cooling system design is forecasted to remain the same during the 1980's as existed in the 1970's. Basically, in the eastern and central section of Texas, power plants will be cooled primarily through the use of once-through cooling systems. Cooling lakes and reservoirs are typically constructed by impounding surface waters. In the western part of the state combined cooling systems, using cooling lakes and towers, or simply evaporative cooling towers will be used to cool the power plants. Major steam electric power plant additions and their method of cooling which are planned for the 1980's include; Comanche Peak 1 \& 2 nuclear fueled (once through reservoir), Twin 0aks $1 \& 2$ lignite (once through reservoir), South Texas $1 \& 2$ (coal) (tower and once through reservoir), Limestone $1 \& 2$ (coal) (once through reservoir), and Fayette Power Project $2 \& 3$ (coal) (once through reservoir).

\subsubsection{Electric Power Region 24}

The Rocky Mountain Power Area, Electric Region 24, encompasses the entire state of Colorado, the eastern half of Wyoming, and a portion of southwestern South Dakota. 
Transmission facilities within the region are limited and although the generating capacity is generally felt to be adequate, coordinated operation within the region is minimal. However, numerous transmission additions are presently being incorporated into the system which should improve the coordination and sharing of load.

The installed capacity of the region in 1979 was approximately $6.5 \mathrm{GW}$. A breakdown of this capacity by energy type shows; 3 GW supported by coal, 2 GW supported by hydro, 0.2 GW nuclear, with the balance using oil and gas. The installed capacity of this electric region is forecasted to double during the 1980's. The installed capacity in 1990 is forecasted to be approximately $13 \mathrm{GW}$.

The Pawnee Power Plant (coal fired) will be cooled using conventional wet cooling towers. Makeup water will be supplied by well and a brine or waste water concentrator will be used for purposes of recycling the blowdown. Planned capacity of the Pawnee Power Plant is $950 \mathrm{MW}$. The Craig Power Plant (coal fired) will use conventional wet evaporative cooling towers. The total capacity to be added at the Craig Power Plant is $800 \mathrm{MW}$.

\subsubsection{Electric Power Region 26}

The Arizona-New Mexico Power Area (Electric Region 26) encompasses Arizona, most of New Mexico, a small portion of Southeastern California, and the tip of Northwestern Texas in the vicinity of EI Paso. This electric region has major connections with three other electric regions; an interconnection, consisting of two 500-kV, one 287-kV, and five 230-kV tie lines with the California-Nevada Power Area (Electric Region 27), a 345-kV interconnection with the Northwest Power Pool east group area (Electric Region 30), and an interconnection between the Rocky Mountain Power Area (Electric Region 24) consisting of one $230-k V$ line and two $345-k V$ lines.

The present installed capacity of the electric region is approximately $11 \mathrm{GW}$. The major portion of the area's generation capacity is derived from 
the use of coal. About one-third of the total region generation was from oil/gas-fired power plants. The installed capacity of the electric region is forecasted to increase by approximately $8 \mathrm{GW}$ during the 1980's (1980 to 1989)(12,13) of the $8 \mathrm{GW}$ planned for installation during the 1980's, all but 45-MW will be fueled by either coal or nuclear energy. A 45-MW geothermal facility at Baca Ranch, New Mexico is scheduled to commence operation in 1982 .

In Electric Region 26, approximately 50\% of the electrical capacity installed during the 1980's will use either reclaimed water or advanced cooling technology. The San Juan Power Plant Unit 3, (coal fired) uses wet/dry cooling towers. Unit 3 uses the first wet/dry cooling tower to be installed in this country for purposes of conserving water and was placed in operation during 1980, and has performed we 11. The system is designed to use $50 \%$ of the normal evaporative requirement at design conditions and over the course of a year is designed to save $80 \%$ of the water consumed by an a11-wet tower. Unit 4 is scheduled for operation in 1982, and as currently planned, a wet evaporative system will be used.

The Palo Verde Nuclear Power Plant will be cooled using wet evaporative cooling towers. Makeup water for the units will be reclaimed from municipal waste water. The reclaimed waste water will be transported approximately 40 miles to the power plant site. The three Palo Verde Nuclear Units are scheduled for startup during the mid-1980's.

\subsubsection{Electric Power Region 27}

The Southern California-Nevada Power Area (Electric Region 27) covers the area of Southern California and Southern Nevada. As of December 1979, the majority of the region's high voltage transmission was rated at $230-k V$ and totaled more than 4600 miles. Strong 500-kV interties exist between Los Angeles, Southern Nevada, Arizona, and New Mexico to the east, and to the north through northern California to the Pacific Northwest, a 750-kV intertie exists. 
The installed capacity at the beginning of 1980 was $25.6 \mathrm{GW}$. During the 10-year period 1980 to 1989, the installed capacity of the region is forecasted to increase by $12.3 \mathrm{GW}$.

The major power plant additions which are planned during the 1980 's include the Allen Power Plant (coal-fired) in South Nevada with a planned total capacity of $2000 \mathrm{MW}$, the Warner Power Plant (coal-fired) in southeastern Nevada with a planned total capacity of $500 \mathrm{MW}$, the Inter-Mountain Power Project located in Utah with a planned capacity of $3000 \mathrm{MW}$, and the Lucerne Valley Power Plant (cogeneration) with a planned combined capacity of $1300 \mathrm{MW}$. A total of 2300 MW of capacity is planned to be added at the San Onofre Nuclear Power Station. As presently planned, the Allen Power Plant will be cooled using wet evaporative towers. Municipal waste water from the City of Las Vegas will be used as makeup. Two existing plants, the Clark Power Station, and the Sunrise Power Station, both located in Southern Nevada, use municipal waste water as cooling water makeup. The Lucerne Valley Power Plant is a combined cycle unit using both gas turbines and combustion boilers. A coal gasification facility will be installed at the site to provide fuel for both facilities. Makeup water will be provided from the California aquaduct. The Inter-Mountain Power Station to be located in Utah will use conventional wet evaporative cooling towers. Water makeup will be provided from purchased water rights obtained from agricultural sources. Condenser cooling for San Onofre units $2 \& 3$ will be provided using once through cooling water from the Pacific Ocean.

\subsubsection{Electric Power Region 28}

Electric Power Region 28 is located in Northern California and Northwest Nevada. The Northern California portion of the electric region has a major tie with the West Group of the Northwest Power Pool. A 500-kV intertie exists between Electric Energy Region 28 and the Northwest Power Pool. The interconnection between Northern Cal ifornia and Northwestern Nevada is 
1 imited, consisting of two 115-kV 1ines. Northern Nevada interconnects with the East Group of the Northwest Power Pool in Utah and in Southern Idaho.

The electrical capacity of this electrical energy region was approximately $16 \mathrm{GW}$ in January 1980. The planned capacity addition for the region is forecasted to be $11.1 \mathrm{GW}$ during the 1980's. Approximately $40 \%$ of the region's capacity results from hydrogeneration. Other generating capacity includes $0 i 1 /$ gas-fueled, geothermal, and nuclear.

Major capacity additions planned for during the 1980's include; Diablo Canyon (nuclear) 1 and 2, the Geysers (geothermal), North Valley (gas 1 and 2), and Montezuma (gas 1 and 2). 
1. D. E. Peterson and J. C. Sonnichsen, Assessment of Requirements for Dry Cooling, HEDL-TME 76-82, Hanford Eng ineering Development Laboratory, Richland, WA, September 1976.

2. Water Supply Should Not be an Obstacle to Meeting Energy Development Goals, CED-30-30 Government Accounting Office, Washington, DC, January 1980.

3. H. V. Clukey, Future Needs for Dry and Peak Shaved Dry/Wet Cooling and Significance to Nuclear Power Plants, EPRI NP-150, Electric Power Research Institute, Palo Alto, CA, February 1976.

4. B. M. Johnson, Dry Cooling of Power Generating Stations: A Summary of the Economic Evaluations of Several Advanced Concepts via a Design Optimization Study and a Conceptual Design and Cost Estimate, BNWL-2120, Pacific Northwest Laboratory, Richland, WA, September 1976.

5. Monthly Energy Review, DOE/EIA-0035, (81/07) A Monthly Publication by the US Department of Energy, Washington, DC, July 1981.

6. Annual Report to Congress, 1980, Volume 3, DOE/EIA-0173(80)/3, US Department of Energy, Washington, DC, March 1981.

7. Statistical Abstract of the United States 1978, Annual Edition, US Department of Commerce, Washington, DC, 1978.

8. Energy Projections to the Year 2000, DOE/PE-0029, Department of Energy, Washington, DC, JuTy 1981.

9. "Research Progress Review," EPRI Journal, Electric Power Research Institute, Palo Alto, CA, January/February 1981.

10. "Sales Rise 1.8\% This Year; the 1980's Outlook is Strong", Electrical World, McGraw Hi11, New York, NY, September 1981.

11. Modern Energy Technology, Vol. 1, Research and Educational Association, New York, NY, 1975.

12. Electric Power Supply and Demand for the Contiguous United States 1980-1989, D0E/RG-0036, US Department of Energy, washington, DC, June 1980 .

13. Electric Power Supply and Demand for the Contiguous United States 1980-1989, DOE/RG-0048, US Department of Energy, Washington, DC, June 1980 . 
14. The Nation's Water Resources 1975-2000 Vol 1: Summary Second National Water Assessment Water Resources Council, US Water Resources Counc i1, Washington, DC, December 1978.

15. The Nation's Water Resources, US Water Resources Council, Washington, DC, 1968.

16. "Federal Water Policy -- Message to Congress," Public Papers of the President, Jimmy Carter, Vol I, p 1044, US Government Printing Office, Washington, DC, June 6, 1978.

17. The Nations Water Resources, 1975-2000 Volume 3: Appendix 3 Monthly Water Supply and Use Analys is, US Water Resources Council, Washington DC, December 1978.

18. Great Lakes Bas in Framework Study Geology and Groundwater Appendix 3 Great Lakes Planning Commission, Ann Arbor, MI, 1965.

19. Yellowstone River Basin, Montana Department of Natural Resources and Conservation, Helena MT, December 1976.

20. W. A. Pettyjohn, A Ground-Water Quality Atlas of the United States, National Demonstration Water Project, Washington DC, 1979.

21. R. F. Probstein, H. Gold, water in Synthetic Fuel Production, MIT Press, Cambridge, MA, 1978.

22. G. Gould, State Water Law in the West: Implications of Energy Development, LA-7588-MS, Los ATamos National Laboratory, Los ATamos, NM, January 1979.

23. R. J. 01sen, MULTIREGION: A Simulation Forecasting Model of BEA Economic Area Population and Employment, ORNL/RUS-25, 0ak Ridge National Laboratory, Oak Ridge, TN. October 1977.

24. L. D. Jacobson, J. C. Sonnichsen, Water Use Information System, HEDL-TME 79-38, Hanford Engineering Development Laboratory, Rich 1 and, WA, September 1979.

25. Water Resources Council, "Synthetic Fuel Development for the Upper Missouri River Basin; Water Assessment, "US Federal Register, Washington DC, October 29, 1980. 